\title{
Working
}

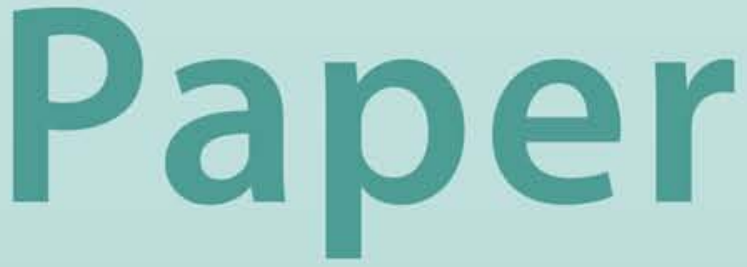




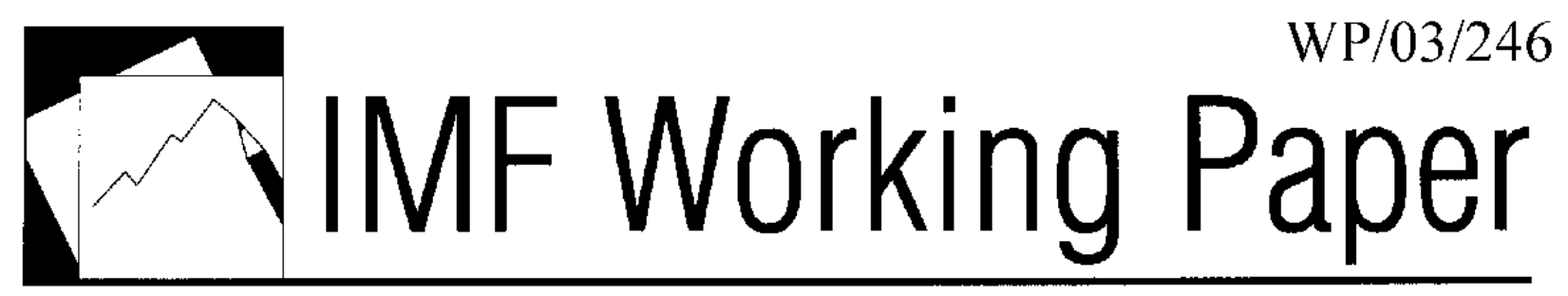

\title{
Volatility and Comovement in a Globalized World Economy: An Empirical Exploration
}

\author{
M. Ayhan Kose, Eswar S. Prasad, and \\ Marco E. Terrones
}




\title{
IMF Working Paper
}

$\Lambda$ sia and Pacific Department, Research Department and Western IIemisphere Department

\section{Volatility and Comovement in a Globalized World Economy:} An Empirical Exploration

\author{
Prepared by M. Ayhan Kose, Eswar S. Prasad, and Marco E. Terrones ${ }^{1}$
}

December 2003

\begin{abstract}
This Working Paper should not be reported as representing views of the IMF. The views expressed in this Working Paper are those of the author(s) and do not necessarily represent those of the IMF or IMF policy. Working Papers describe research in progress by the author(s) and are published to elicit comments and to further debate.
\end{abstract}

This paper analyzes the evolution of volatility and cross-country comovement in output, consumption, and investment fluctuations using two distinct datasets. The results suggest that there has been a significant decline in the volatility of business cycle fluctuations and a slight increase in the degree of cyclical comovement among industrialized countries over time. However, for emerging market economies, financial globalization appears to have been associated, on average, with an increase in macroeconomic volatility as well as declines in the degree of comovement of output and consumption growth with their corresponding world aggregates.

JEL Classification Numbers: F2, F41, F42, E32

Keywords: Business cycles; macroeconomic fluctuations; volatility; correlations; globalization

Authors' E-Mail Addresses: akose@imforg; cprasad@imforg; mterronos@imforg

\footnotetext{
${ }^{1}$ This paper was prepared for the 2003 Kiel Week Conference on "Macroeconomic Policies in the World Economy" organized by the Kiel Institute for World Economics and will be published in the conference volume. This is a revised version of an earlier paper circulated under the title "Globalization and Business Cycle Comovement." We thank Mike Artis, Ray Barrel, Michael Bordo, Hideaki Hirata, Rolf Langhammer, Enrique Mendoza, Martin Mühleisen, Horst Siebert, Chris Towe, Ted Truman, and our discussant, Linda Tesar, for helpful comments and suggestions. We thank Song-Yi Kim and Gustavo Ramirez for excellent research assistance.
} 


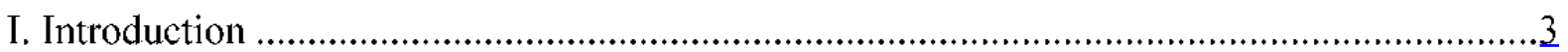

II. Growing Linkages and Business Cycles in Economic Theory …...................................

A. Effects of Globalization on Volatility ...........................................................

B. Effects of Globalization on Comovement ......................................................... 5

III. Growing Global Linkages.................................................................................. 6

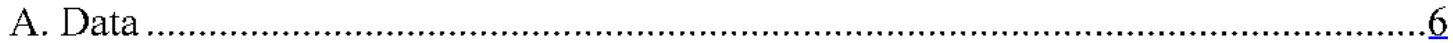

B. A Useful Demarcation of the Periods .......................................................

C. A Globalized World Economy ..................................................................... 8

IV. Dynamics of Volatility and Comovement: An Aggregate Perspective ..............................

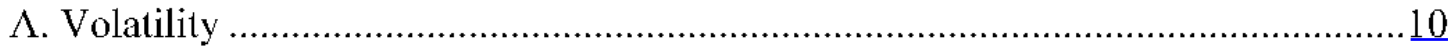

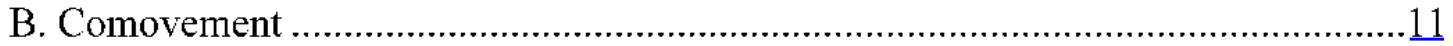

C. Can Changes in Volatility IIelp to Explain the Changes in Comovement?...........13

D. Explaining the Evolution and Sources of Comovement .....................................13

V. Dynamics of Volatility and Comovement in the Group of Seven (G-7) Countries...........15

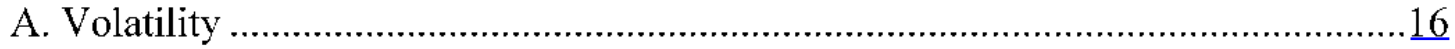

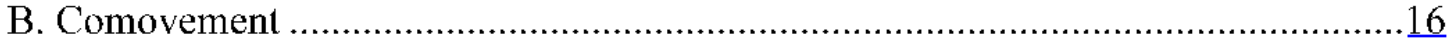

C. Explaining the Evolution and Sources of Comovement in the G-7 Countries........17

VI. Conclusions............................................................................................

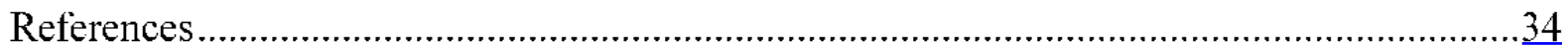

Tables

1. Volatility of Annual Growth Rates of Selected Variables.......................................

2. Correlations with "World" Macroeconomic Aggregates..........................................2]

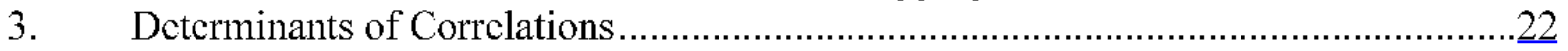

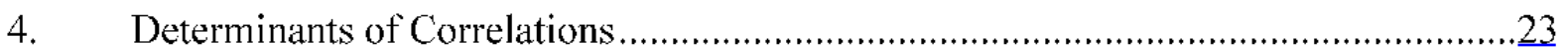

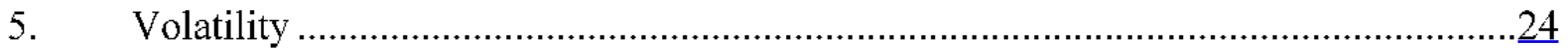

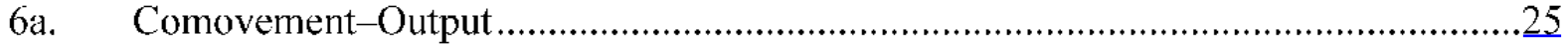

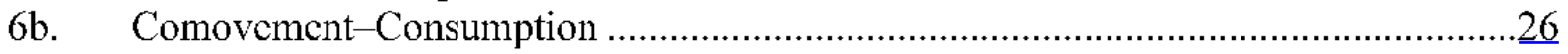

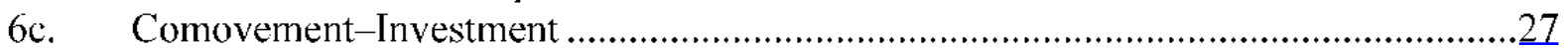

7a. Average Variance Explained by the World Factor ..............................................28

7b. Output Variance Explained by the World Factor ................................................28

Figures

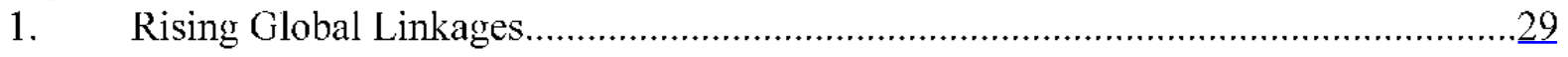

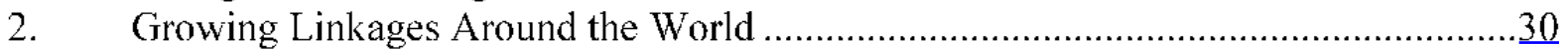

3. Growing Linkages Among the G-7 ................................................................. 31

4. Output, Consumption, and Investment Volatility ..........................................32

5. Output, Consumption, and Investment Correlation .............................................33 


\section{INTRODUCTION}

Trade and financial linkages across national economies have increased rapidly in recent decades. Industrial countries have actively participated in the process of globalization for many decades, developing countries have also become active participants in recent years. Thus, the interdependence of the global economy now extends across a far broader range of countries than ever before. Recent research has attempted to analyze the effects of various aspects of globalization on growth. ${ }^{2}$ Less attention has been paid to the effects of globalization on shorter-term macroeconomic fluctuations, particularly in developing economies. This is an important issue from both academic and policy perspectives. For instance, the degree of synchronization of fluctuations across countries has implications for the international coordination of macroeconomic policies. In addition, the extent of cross-border spillovers of business cycle fluctuations can affect the conduct and effectiveness of domestic stabilization policies, especially in developing economies that are intrinsically more volatile.

In this paper, we provide a comprehensive empirical characterization of changes in two key aspects of business cycle fluctuations - volatility and comovement. In particular, our paper extends the research program on the dynamics of business cycles in three dimensions. First, we look at the evolution of volatility and comovement in three major macroeconomic aggregates: output, consumption, and investment. This allows us to relate our results more closely to the implications of different theoretical models concerning the effects of global trade and financial integration on macroeconomic fluctuations. Second, unlike previous studies that have looked at the properties of volatility and comovement separately, we also examine whether their evolutions over time are interlinked in some respects. An additional contribution of this paper comes from the fact that our analysis encompasses a large and varied set of industrial, middle-income, and low-income developing economies. Much of the existing literature has focused only on industrial economies.

Although we do not test any particular theoretical model, theory nevertheless provides a useful guide to understanding and interpreting our results. In Section II, we provide a brief summary of the implications of economic theory concerning the relationship between increased economic linkages and the volatility and comovement of cyclical fluctuations, measured by stationary components or growth rates of the major macroeconomic aggregates. This section shows that although theory is unable to provide clear guidance about the impact of increased trade and financial linkages on the volatility and cross-country correlations of output fluctuations, it appears to have unambiguous predictions about the role of stronger linkages on the cyclical properties of consumption and investment.

In Section III, we first provide some details about two distinct datasets employed in the paper. The first dataset is useful in analyzing the properties of business cycles in a large

\footnotetext{
${ }^{2}$ Prasad, Rogoff, Wei, and Kose (2003) analyze the dramatic increase in financial linkages between industrialized countries and developing economies and survey the literature on the impact of these linkages on growth.
} 
group of industrial and developing countries. Our second dataset is used to examine the features of business cycles in the Group of Seven (G-7) countries. We consider the period from 1960 to 2002 as being composed of three distinct subperiods, which helps us to isolate the impact of common shocks from that of globalization. We document some stylized facts about the growth in trade and financial linkages over time to motivate our choice of these subperiods.

In Section IV, we provide a basic empirical characterization of macroeconomic fluctuations, in terms of both comovement and volatility, for a large sample of industrial and developing countries using our first dataset. In order to get a better understanding of the impact of financial integration on business cycles in developing countries, we divide developing countries into two coarse groups - more financially integrated (MFI) economies and less financially integrated (LFI) economies. For analyzing comovement, we use an aggregate of output, consumption, or investment for the G-7 economies as a measure of "world" output, consumption, and investment, respectively. This section also provides a discussion about the sources of business cycle comovement in our large dataset. In order to provide a more complete description of the evolution of business-cycle properties in advanced countries, we employ our second dataset and analyze the volatility and comovement properties of the G-7 economies in greater detail in Section V. This section also briefly discusses the sources of comovement in these countries. Section VI concludes the paper.

\section{Growing LinKages aNd BuSiness CyCles in ECONOMIC ThEORY}

This section briefly reviews theoretical implications of increased trade and financial linkages for volatility and cross-country comovement of business cycles.

\section{A. Effects of Globalization on Volatility}

Existing theoretical models do not yield a uniform prediction about the effects of globalization on the volatility and comovement properties of national outputs. For example, across different theoretical models, the direct effects of global integration on output volatility are ambiguous. Financial integration provides access to capital that can help capital-poor developing countries to diversify their production base. On the other hand, rising financial integration could also lead to increasing specialization of production based on comparative advantage considerations, thereby making economies more vulnerable to shocks that are specific to industries (see Razin and Rose (1994)).

Irrespective of the effects on output volatility, theory suggests that financial integration should reduce consumption volatility. The ability to reduce fluctuations in consumption is regarded as an important determinant of economic welfare. Access to international financial markets provides better opportunities for countries to share macroeconomic risk and, thereby, smooth consumption. The basic idea here is that, since output fluctuations are not perfectly correlated across countries, trade in financial assets can be used to delink national consumption levels from the country-specific components of these output fluctuations (see Obstfeld and Rogoff (1998), Chapter 5). 
Theory also predicts that stronger financial and trade linkages should increase the volatility of investment. When restrictions on capital and current account transactions are reduced, substitution possibilities between domestic and foreign investment get expanded, which in turn results in an increase in investment volatility. If reductions in the restrictions on capital account transactions coincide with persistent country-specific shocks, this would further increase the volatility of investment (see Razin and Rose (1994)). Increased trade and financial linkages lead to larger investment variation in open economy dynamic stochastic business cycle models as this induces more "resource shifting", through which capital and other resources rapidly shift to the country receiving the more favorable productivity shock (see Mendoza (1994), and Heathcote and Perri (2002a)).

\section{B. Effects of Globalization on Comovement}

Economic theory does not provide definitive guidance concerning the impact of increased trade and financial linkages on the degree of synchronization of output fluctuations (see Heathcote and Perri (2002a, 2002b) and Kose and Yi (2003)). International trade linkages generate both demand and supply-side spillovers across countries. For example, on the demand side, an investment or consumption boom in one country can generate increased demand for imports, boosting economies abroad. Through these types of spillover effects, stronger international trade linkages can result in more highly correlated cycles in output across countries. However, trade flows could also induce increased specialization of production resulting in changes in the nature of business cycle correlations. If stronger trade linkages are associated with increased inter-industry specialization across countries, and industry-specific shocks are important in driving business cycles, then the degree of output comovement might be expected to decrease.

Financial linkages could result in a higher degree of synchronization of output fluctuations by generating large demand-side effects. For instance, if consumers from different countries have a significant fraction of their investments in a particular stock market, then a decline in that stock market could induce a simultaneous decline in the demand for consumption and investment goods in these countries. Furthermore, contagion effects that are transmitted through financial linkages could also result in heightened cross-country spillovers of macroeconomic fluctuations.

International financial linkages could stimulate specialization of production through the reallocation of capital in a manner consistent with countries' comparative advantage in the production of different goods. Such specialization of production, which could result in more exposure to industry- or country-specific shocks, would typically be expected to be accompanied by the use of international financial markets to diversify consumption risk (see Kalemli-Ozcan, Sorensen and Yosha (2003)). More generally, financial integration, by helping countries to diversify away country-specific risk associated with consumption fluctuations, should result in stronger comovement of consumption across countries. This effect would be expected to be stronger for developing countries that are typically less diversified in terms of their endowment and production structures and have intrinsically more volatile output, implying that their potential gains from international risk sharing are even greater than for industrial countries. 
In theory, stronger trade and financial linkages should result in lower investment correlations across countries because of the resource shifting effect discussed above. In particular, as restrictions on capital and current account transactions are reduced, the resource shifting effect should become stronger. Capital flows to the country with the highest return (or the country with more favorable productivity shocks) would lead to lower cross-country investment correlations (see Cole (1993) and Heathcote and Perri (2002a)).

\section{Growing Global Linkages}

This section first provides information about the data used in our empirical analysis. It then considers the major events of the past four decades and proposes a useful demarcation which helps us to isolate the impact of common shocks from that of globalization on the properties of business cycles. The section then provides some empirical evidence about the growth of trade and financial linkages during the past four decades.

\section{A. Data}

We analyze the dynamics of volatility and comovement using two distinct datasets. In section IV, we use a large dataset that includes industrial as well as developing countries. This dataset comprises annual data over the period 1960-1999 for a sample of 76 countries21 industrial and 55 developing. ${ }^{3}$ Per capita real GDP, real private consumption, and real investment constitute the measures of national output, consumption, and fixed investment, respectively. We divide developing countries into two coarse groups-more financially integrated (MFI) economies and less financially integrated (LFI) economies. The former essentially constitute the group of "emerging markets" and account for a substantial fraction of net capital flows from industrial to developing countries in recent decades. The group of industrial countries corresponds to a sub-sample of the OECD economies for which data used in the empirical analysis are available. We use this grouping only in the descriptive part of the empirical analysis. The regression analysis in section IV.B is based on different measures of financial integration. In section $\mathrm{V}$, we turn our attention to the G-7 countries and examine the dynamics of volatility and comovement using quarterly data on output, consumption, and investment for the period 1960:1-2002:4. ${ }^{4}$

\section{B. A Useful Demarcation of Time Periods}

Considering the time period of 1960-2002 we are interested in studying, it is essential to isolate the impact of common shocks from that of globalization in order to evaluate the effects of globalization on the features of business cycles over time. Following Kose, Otrok, and Whiteman (2003b), we consider the period from 1960 to 2002 as being composed of three distinct sub-periods. The first period, 1960:1-1972:2, corresponds to the Bretton Woods (BW) fixed exchange rate regime for the major industrial countries. This sub-period

\footnotetext{
${ }^{3}$ For a description of the data and sources, see Kose, Prasad, and Terrones (2003a).

${ }^{4}$ Hirata, Kose, and Prasad (2003) provide a description of the data and sources.
} 
is characterized by the steady nature of growth and relatively stable business cycles around the world. The second period, 1972:3-1986:2, witnessed a set of common shocks associated with sharp fluctuations in the price of oil and contractionary monetary policy in major industrial economies. Of course, the first and second periods are also different because of the difference in exchange rate regime. ${ }^{5}$ The third period, 1986:3-2002:4, represents the globalization period in which there were dramatic increases in the volume of cross-border asset trade. ${ }^{6}$

There are at least three major differences between the common shock period ( $2^{\text {nd }}$ period) and the period of globalization ( $3^{\text {rd }}$ period). First, there has been a substantial increase in the volume of trade and financial flows since the mid-1980s. For example, Prasad, Rogoff, Wei, and Kose (2003) document that private capital flows from industrialized economies to developing economies have increased dramatically since the mid-1980s (Figures la and 1b). The bulk of this increase has gone to the MFI economies. Heathcote and Perri (2002b) provide evidence that U.S. holdings of foreign assets have grown significantly since the mid1980 s, rising from 8 percent in 1986 to roughly 35 percent of the total U.S. capital stock in 1999 (Figure 1c). $^{7}$

Second, the globalization period also coincides with a substantial increase in international trade flows (Figure 1d). During this period, both developed and developing countries intensified their efforts to liberalize external trade regimes and the number of regional trade agreements increased from 28 in 1986 to 181 in 2002 . The next section provides a more detailed account of the increase in global trade and financial linkages for different groups of countries and for the three sub-periods under study. Third, as we have already stated above, the period of common shocks witnessed sharp fluctuations in the price of oil and a set of contractionary monetary policies in the major industrial economies that have not characterized the most recent period.

\footnotetext{
${ }^{5}$ However, it is debatable whether (and how) the monetary regime affects the properties of business cycles in main macroeconomic aggregates. For example, Baxter and Stockman (1989), Baxter (1991), and Ahmed, et. al. (1993) find that different exchange rate regimes do not result in significant changes in the behavior of the main macroeconomic aggregates. On the other hand, Gerlach (1988) concludes that the exchange rate regime does have an impact on the stylized features of business cycle.

${ }^{6}$ In the case of annual data, we assume that these three periods correspond to the following: 1960-1972, 1973-1986, and 1987-1999.

${ }^{7}$ See Heathcote and Perri (2002b) for a detailed discussion of the data series used to draw this figure.
} 


\section{A Globalized World Economy}

There has been a substantial increase in the volume of international trade and financial flows during the past four decades. This subsection first documents the major trends associated with this increase using the data from our large sample which includes both industrialized and developing countries. Then, increased global linkages among the G-7 countries are analyzed.

\section{Growing Economic Linkages Around the World}

There has been a dramatic increase in the overall volume of international trade over the last three decades (Figure 1d). For example, the growth rate of world trade has been larger than that of world income in almost all years since 1970. The average growth rate of trade, measured by the sum of exports and imports, has been more than two times larger than that of GDP in the groups of industrial and MFI countries during the period of globalization (Figure 2a). Reductions in trade barriers and declines in transport and communications costs have both played important roles in driving the rapid growth in trade. In particular, both MFI and LFI countries reduced average tariff rates from around 30 percent in the 1980 s to about 18 percent in the late 1990 s.

MFI countries have been much more successful in diversilying their export base and increasing their exports. While both MFI and LFI countries have increased the share of manufactured goods exports in their total exports, the average share of exports of primary goods in total exports is still much higher for LFIs ( 49 percent) compared with the MFIs (19 percent). This implies that LFIs have remained more vulnerable to the volatility in world commodity prices.

Another major change in trade patterns is the phenomenon of vertical specialization, wherein countries specialize in particular stages of a good's production sequence, rather than the entire product. There is more "back-and-forth" trade, in which a product crosses multiple borders while in-process. This gencrates a vertical trading chain that stretches across many countries. The increasing interconnectedness of production processes in this vertical trading chain has resulted in the "internationalization of production." Recent research shows that vertical specialization rose almost 30 percent from the 1970 s to the 1990 s and it accounts for more than 20 percent of exports in several industrialized and MFI countries (see Hummels, Ishii, and Yi (2001) and Chen and Yi (2003)). More importantly, vertical specialization accounted for 30 percent of the growth in those countries' exports.

Gross private capital flows have also increased dramatically during the period of globalization (Figure 2b). While MFI countries have been able to register a substantial increase in the volume of gross private capital flows in the globalization period, the increase in the volume of flows to LFI countries has been relatively small. The main increase in gross capital flows to developing countries has been in terms of FDI and portfolio flows, while the relative importance of bank lending and official flows (including loans and grants) has declined over time (Figures $1 \mathrm{a}$ and $1 \mathrm{~b}$ ). Net portfolio flows also show a similar pattern, 
although both flows to MFI economies fell sharply following the Asian crisis and have remained relatively flat since then.

\section{Growing Economic Linkages Among the G-7 Countries}

The Group of Seven (G-7) countries have also experienced a substantial increase in trade and financial flows during the past four decades. ${ }^{8}$ The average growth in international trade, measured by the sum of exports and imports, has been more than two times larger than that of output in the $\mathrm{G}-7$ countries during the past four decades (Figure $3 \mathrm{a}$ ). The growth rate of international trade relative to that of output has increased dramatically during the period of globalization in the United States and other G-7 countries. For example, U.S. trade has grown at a rapid pace reaching about 20 percent of GDP in 2002. Unlike other G-7 countries, Japan's international trade has recorded a smaller increase in its growth relative to GDP. While the openness ratio of the United States (Germany) has increased from an average of 5 (30) percent during the Bretton Woods period to 20 (45) percent during the globalization period, the openness ratio of Japan has hovered around 20 percent during the past four decades. Interestingly, the relative importance of trade among the G-7 countries has been quite stable over time (Figure $3 b$ ). ${ }^{9}$ Trade based on vertical specialization in the G-7 countries has also grown over the years and now accounts for a sizeable fraction of total exports (Figure $3 \mathrm{c}$ ). ${ }^{10}$ Since this type of specialization generates a vertical trading chain stretching across many countries, it makes international trade a potentially more powerful channel of business cycle transmission (see Yi (2003) and Kose and Yi (2003)).

A more dramatic element in the process of globalization has been the surge in international capital flows over the past three decades. For the United States (Germany) international capital flows, measured by gross foreign direct investment flows plus other types of capital flows, have jumped from less than 7 (7) percent during the period of common shocks to more than 13 (20) percent of GDP in the globalization period (Figure 3d). In the G-7 countries, this ratio has, on average, increased more than twofold during the globalization period.

\section{DYNamics of Volatility and Comovement: AN AggRegate Perspective}

We first present some stylized facts concerning output, consumption, and investment volatility using the data of industrial and developing countries in this section. Next, we

\footnotetext{
${ }^{8}$ Kose (2003) examines the growth in trade and financial linkages among the G-7 countries and changes in the U.S. business cycles over time.

${ }^{9}$ In the case of Japan, the evolution of trade intensity with other G-7 countries over time has been influenced by the country's heavy reliance on oil imports, see Hideaki (2003) for details.
}

${ }^{10}$ See Chen and Yi (2003) for detailed information about the data used in producing this figure. 
examine some summary statistics on the correlations of growth rates of the major macroeconomic variables of each country with the growth rates of the composite measures of corresponding world aggregates. This is followed by a brief discussion about the role of the changes in the dynamics of volatility in explaining the evolution of comovement over time. We conclude this section by analyzing the sources of comovement using a set of panel regressions.

\section{A. Volatility}

Volatility is measured by the standard deviations of the growth rates of individual country output, consumption, and investment. Table 1 (column 1) shows the cross-sectional medians of the volatility of output, consumption, and investment growth over the full sample, 19601999. The results line up as expected, with median volatility of output, consumption, and investment being lowest for the industrial country sub-sample and, among developing countries, for MFI economies, which tend to be richer and more industrialized than LFI economies. As has been well documented in the literature, the volatility of investment is higher than that of output and consumption. Interestingly, the volatility of consumption is often slightly higher than output. ${ }^{11}$

Of more interest in terms of understanding the effects of globalization on volatility is an examination of changes over time in patterns of macroeconomic volatility. Table 1 (panel 1 , columns 2-4) presents summary statistics for the volatility of output over each of the three specific periods defined above. Median output volatility rises in all groups during the common shock period. During the globalization period, however, median output volatility declines to a level lower than that of even the relatively calm BW period in industrial countries. There is a similar pattern of a sharp decline in output volatility for LFI economies during the globalization period. Output volatility for MFI economies is essentially unchanged in the globalization period relative to the BW period.

The second panel of Table 1 shows the evolution of median volatility of the growth rate of consumption. As one would expect, for all three groups of countries, consumption volatility goes up in the common shock period, relative to the BW period. Then, similar to the behavior of output volatility, the volatility of consumption decreases in the globalization period. In particular, for industrial and LFI economies, there is a sharp and statistically significant decline in consumption volatility in the globalization period, relative to the common shock period. The median volatility of consumption goes down by almost 35 percent (from 2.4 to 1.8 ) in the group of industrialized economies and it decreased by more than 25 percent (from 7.4 to 5.8) in LFI countries. The major difference is again for MFI economies, which experience a much smaller decline of approximately 10 percent (from 5.2 to 4.7 ), in their

${ }^{11}$ The fact that consumption growth is more volatile than output growth suggests a violation of consumption smoothing behavior. Kose, Prasad, and Terrones (2003a) show that this "puzzle" is considerably attenuated if one accounts for government consumption and uses a measure of national income that incorporates a terms of trade adjustment to GDP (or GNP). 
median consumption volatility in the globalization period, relative to the common shock period.

The evolution of the median volatility of the growth rate of investment is presented in the third panel of Table 1. The volatility of investment is highest in the common shock period for industrial and LFI countries. For these two groups, there is a substantial decrease in the volatility of investment in the globalization period, relative to the common shock period. $\mathrm{MFI}$ economies also witnessed a fall in investment volatility, but the magnitude of this decrease is much smaller than those in other country groups. In particular, from the common shock period to the globalization period, the decrease in the volatility of investment is around 25 percent in LFI countries whereas it is less than 10 percent in the MFI economies. Another interesting observation is that the volatility of investment is lower in the globalization period than in the BW period for all groups of countries. This result is not consistent with the theoretical predictions which we discussed in the previous section. However, there is at least one potential explanation of this result: there have been some major structural changes associated with inventory management techniques and production technologies that have helped firms to reduce the volatility of their investment demand during the $1990 \mathrm{~s}$. This could have resulted in the lower volatility of aggregate investment (see McConnell, Mosser, and Quiros (1999) and Stock and Watson (2003)).

Figure 4 shows mean output, consumption, and investment volatility for different groups of countries based on standard deviations of growth rates computed over a 10 -year rolling window. Clearly, the choice of the cross-sectional average measure (mean vs. median) and the breakdown of the data in Table 1 into specific time periods are not crucial to the results we reported. These figures do show that, for MFI countries, the volatility of major macroeconomic aggregates increased further in the late 1990s.

\section{B. Comovement}

Comovement is measured as the correlations of the growth rates of individual country output, consumption, and investment with the growth rates of corresponding "world" aggregates. To minimize the effects of the large economies on the results, we use PPP-weighted aggregates of output and consumption in the G-7 countries as measures of the relevant world aggregates. These countries are then excluded from the empirical analysis in this subsection. The use of G-7 aggregates has some additional advantages. Since the G-7 countries account for a substantial fraction of financial and trade flows to developing countries, correlations with the G-7 aggregates are most relevant for understanding the effects of integration on the degree of business cycle comovement. In any case, as one would expect, cyclical fluctuations in the G-7 countries are highly correlated with fluctuations in total world output.

Table 2 (column 1) shows the cross-sectional medians of the correlations of output, consumption, and investment growth over the full sample period, 1960-1999. Non-G-7 industrial countries have, on average, stronger correlations with world macroeconomic aggregates than developing economies. For the full sample, correlations of output are slightly higher than those of consumption, and investment correlations are the lowest. The first panel of the table presents the correlations of output growth in each subperiod. For industrial 
countries, these correlations on average increase sharply in the common shock period and rise further in the period of globalization. For developing countries, on the other hand, the correlations are in general much lower compared to industrial countries and decline in the globalization period. In fact, for MFI and LFI economies, these correlations become almost zero during the globalization period. Kose, Prasad, and Terrones (2003b) also report that, for MFI economies, the correlations of output fall sharply in the 1990 s relative to previous decades. These results suggest that the degree of business cycle comovement increases slightly in industrialized countries over time. However, the results also indicate that there is little evidence, in terms of other country groups, that business cycle comovements have on average become more synchronized at a global level during the period of globalization.

The second panel of Table 2 shows that the temporal evolution of consumption correlations is quite similar to that of output correlations. In addition, as documented by several other authors, consumption correlations are typically smaller than output correlations. A particularly interesting result is that, for MFI economies-which have received the bulk of international capital flows to developing countries-the median consumption correlation do not increase in the globalization period. This seems at odds with the notion that financial integration should have helped these economies to better share consumption risk with mature industrial economies.

The third panel of Table 2 displays the evolution of investment correlations over the three sub-periods. These correlations display a pattern similar to those of output and consumption correlations. For industrial countries, investment correlations with world investment have increased over time. This is an interesting result because it appears to contradict with economic theory, which implies that stronger economic linkages should lead to lower investment correlations. For developing countries, it is hard to detect a clear pattern except that the correlations are generally close to zero.

Figure 5 shows the average correlations of growth rates of output, consumption, and investment for the three groups of countries with the growth rates of corresponding world aggregates computed over a 10 -year rolling window. These figures are quite consistent with the broad patterns described in Table 2, suggesting that neither the cross-sectional average measure (mean vs. median) nor the breakdown of the data in Table 2 into specific time periods has a major effect on the results. The figures for MFI countries show that the degree of comovement of business cycles in these countries with the world business cycle declined further in the late 1990s, the period during which a number of MFI countries experienced severe financial crises.

In summary, for MFI economies, the experience of financial globalization appears to have been associated, on average, with an increase in some aspects of macroeconomic volatility as well as declines in the degree of comovement of output and consumption growth with their corresponding world aggregates. 


\section{Can Changes in Volatility Help Explain the Changes in Comovement?}

One possibility, suggested by the work of authors such as Doyle and Faust (2002) in the context of business cycles in the G-7 countries, is that changes in volatility may in fact be part of the explanation for the changes in patterns of correlations. At a very simplistic level, it is conceivable that an increase in the volatility of two series, if it was not accompanied by a change in the covariance structure, could mechanically induce a decline in the correlation between those two series. ${ }^{12}$ Can this pattern explain the differences across country groups in the temporal patterns of correlations?

For industrial countries, there appears to be a consistent pattern of a decline in average volatility as well as an increase in average correlations with the world aggregate during the last two periods. We provide a brief analysis of this issue using quarterly data series in section 4. For the developing countries, however, this relationship does not hold since the volatility of all the major macroeconomic variables has on average declined during the globalization period relative to the common shock period. ${ }^{13}$ Their average correlations with the world aggregate have in fact declined in the globalization period. While these results could be challenged on the basis of their statistical (in)significance, it appears difficult to argue that changes in the patterns of volatility provide a sufficient mechanical explanation for the changes in the correlation patterns in the case of developing countries.

\section{Explaining the Evolution and Sources of Comovement}

In this subsection, we examine the empirical relevance of some potential explanations of the comovement patterns documented above. Several recent studies have examined the evolution of the comovement properties of business cycles. Most of these studies focus on the properties of business cycles in industrial countries. A limited number of studies document the properties of business cycles in developing economies. For example, Agenor, Mc Dermott, and Prasad (2000) document the main features of business cycles in twelve developing countries using quarterly data series for the period 1978:1-1995:4. They find that business cycle fluctuations in industrial countries have a significantly positive impact on output dynamics in most of the developing countries. ${ }^{14}$ In a recent paper, Kim, Kose, and Plummer (2003) study the time profile of the properties of business cycles in a set of Asian emerging market countries for the period 1960-96. They find that business cycle fluctuations in the Asian economies exhibit a high degree of comovement. Their results also indicate that

\footnotetext{
${ }^{12}$ Needless to say, it could also be argued that the evolution of volatility is determined by how trade and financial linkages affect a country's vulnerability to external shocks-in other words, how correlated domestic economic activity is with foreign economic activity.

13 The volatility of the world aggregate has also declined in both the 1980 s and 1990 s relative to the 1970 s and 1980 s, respectively.

${ }^{14}$ IMF (2001), Mendoza (1995), and Kose (2002) compare the business cycle characteristics of a group of developed economies with those of some developing countries.
} 
the degree of business cycle comovement has increased over time for the majority of country-pairs they studied.

While the studies documenting the evolutionary dynamics of business cycle comovement are useful, they are unable to provide a direct link between increased global linkages and changes in the time profile of cyclical comovements. Several recent studies examine the impact of increasing trade and financial linkages on cross-country business cycle correlations using more formal econometric methods. For example, running cross-country or cross-region panel regressions, first Frankel and Rose (1998), and then, Clark and van Wincoop (2001), Otto, Voss, and Willard (2001), Calderon, Chong, and Stein (2002), Imbs (2003) and others show that, among industrialized countries, pairs of countries that trade more with each other exhibit a higher degree of business cycle comovement (see Kose and Yi (2003)). Using data for a set of advanced and emerging market economies for the period 1983:1-1998:3, Imbs (2003) finds that the extent of sectoral similarity, the intensity of financial linkages, and the volume of intra-industry trade all have a positive impact on the degree of comovement. Otto, Voss, and Willard (2001) document that the volatility of bilateral exchange rates and some structural characteristics, such as good accounting standards, similar legal systems, common language, and openness to new technologies, significantly effect cross-country business cycle correlations.

Kose, Prasad, and Terrones (2003b) study the impact of increased trade and financial linkages on the correlations between fluctuations in individual country aggregates (output and consumption) and those in corresponding world (G-7) aggregates using the large dataset described in the previous section. In particular, they employ panel regressions in which nonoverlapping ten-year correlations are used as the dependent variable. They consider a variety of explanatory variables along with different measures of trade and financial openness. They report four main results: First, trade openness, measured as the intensity of direct trade relationships with the G-7 (trade with the G-7 as a share of a country's total trade) has a significant and positive impact on output and consumption correlations. Second, countries which are more open to financial flows have higher output correlations with the G-7 aggregate. Third, the volatility of the terms of trade has a statistically significant negative impact on output and consumption correlations. Fourth, the fiscal impulse has a negative impact on cross-country consumption correlations. One possible interpretation of this last result is that fiscal policies could exacerbate country-specific fluctuations which in turn reduce correlations between domestic consumption and the world consumption.

We extend this study by introducing a couple of potentially important policy variables into their regression framework. In particular, we analyze the importance of fiscal and monetary policy similarity (coordination) in driving output and consumption correlations. In theory, the impact of policy coordination on the degree of output comovement is ambiguous. On one hand, coordinated policies could lead to a higher degree of output correlations if these policies are considered as common shocks generating business cycles. On the other hand, coordination of policies, e.g., common policy in a monetary union, could induce less correlated business cycles if the strict imposition of coordinated policies prevents policy makers from implementing policies to deal with country-specific shocks. The implication of 
this brief discussion is that, as Clark and van Wincoop (2001) also argue, this is essentially an empirical question.

Unfortunately, data limitations force us to employ relatively crude measures of policy coordination. The extent of the similarity of a particular country's fiscal policy to that of the G-7 aggregate is measured by the volatility of the difference between the fiscal impulse of the particular country and that of the G-7 aggregate. A similar measure is also used by Clark and van Wincoop (2001). To measure the degree of similarity of monetary policy of a country to that of the G-7 aggregate, we use the volatility of the difference between the inflation rate of the particular country and that of the G-7 aggregate. Table 3 presents the results from OLS regressions and instrumental variable (IV) regressions. We instrument for the trade and financial integration variables in our IV regressions which allow us to isolate the effects associated with possible endogeneity issues and mitigate the problems associated with measurement errors in the data.

The results are mostly in line with the findings in Kose, Prasad, and Terrones (2003b). In particular, the intensity of trade linkages with the G-7 leads to a higher degree of business cycle correlations while the volatility of the terms of trade reduces the extent of business cycle comovement. Neither the similarity of fiscal policy nor that of monetary policy has a statistically significant impact on the degree of output comovement. This result is consistent with the findings in Clark and van Wincoop (2001) and Imbs (2003). In the case of consumption correlations, our findings suggest that the extent of monetary policy similarity has no impact. However, the variable associated with the [dis]similarity of fiscal policies has positive impact on consumption correlations indicating that less similar fiscal policies may lead to higher consumption correlations.

Kose, Prasad, and Terrones (2003b) measure the degree of current account restrictions by the extent of payment restrictions on current account transactions. They report that this variable has no significant impact on output and consumption correlations. We extend their study by employing an alternative measure of current account restrictions which captures the extent of government interference with foreign trade (Table 4). ${ }^{15}$ This measure was first developed by Sachs and Warner (1995) and recently updated by Easterly, Lane, and Roodman (2003). We find that the main results regarding output and consumption correlations are robust to the measure of current account restrictions we have used.

\section{Dynamics of Volatility and Comovement in THE Group OF Seven (G-7) CounTries}

We now turn our attention to the G-7 countries and examine the dynamics of volatility and comovement using quarterly data on output, consumption, and investment for the

\footnotetext{
${ }^{15}$ A country is considered open to trade if it satisfies a variety of criteria according to this measure. Sachs and Warner (1995) provide detailed information about this variable.
} 
period 1960:1-2002:4. ${ }^{16}$ This section first documents how the properties of volatility and comovement of business cycles in these variables have changed over time as global linkages have increased. Next, we provide a brief analysis about the evolution and sources of comovement in the $\mathrm{G}-7$ countries.

\section{A. Volatility}

Table 5 presents the volatility of the growth rates of output, consumption, and investment in the G-7 countries. As several earlier studies have documented, the volatility of investment is two to three times greater than those of output and consumption for the full period. The average volatility of all three variables decreases during the globalization period relative to the period of common shocks.

The volatility of all three variables in the United States decreases significantly in the globalization period relative to the common shock period. Several recent studies also report that there has been a steady decrease in the volatility of U.S. output and its components since the mid-1980s (see McConell and Quiros (2000), Blanchard and Simon (2001), Stock and Watson (2003), and Smith and Summers (2002)). Explanations for this decline in volatility are many, ranging from "new economy" driven changes in some sectors to the effectiveness of monetary policy during the recent period.

Another interesting result is that, for all countries except Japan, the volatility of all three variables typically goes down during the globalization period relative to the common shock period. In Japan, while the volatility of investment has moderated over time, the volatility of output and consumption has increased slightly in the globalization period relative to the common shock period. Hideaki (2003) also documents that business cycles in consumption and investment have become more volatile in Japan during the past fifteen years. In all countries except Germany and Japan, there is a decline in the volatility of consumption during the globalization period relative to the BW period. ${ }^{17}$

Overall, our results indicate that there has been a dampening of business cycle volatility in most of the G-7 countries over time. This complements our earlier findings that suggest a decline in the average volatility of business cycles over time in a larger set of industrial countries.

\section{B. Comovement}

As before, the degree of comovement is measured by correlations of the growth rates of output, consumption, and investment. Cross-country correlations of these aggregates for the United States, Germany, and Japan with those of other G-7 countries are presented in

${ }^{16}$ Hideaki, Kose, and Prasad (2003) provide more detailed tests of statistical significance for some of the results reported in this section.

${ }^{17}$ In a recent paper, Buch, Doepke, and Pierdzioch (2002) find that output volatility has declined in Germany over the period 1970-2000. 
Tables $6 \mathrm{a}, 6 \mathrm{~b}$, and $6 \mathrm{c}$. Our results are in line with the earlier findings in the literature as cross-country output correlations are higher than those of consumption and investment. The results also indicate that the average correlations for the three countries are generally highest during the common shock period.

It is useful to compare the correlations in the globalization period with those in the BW period to isolate the role of globalization in driving the degree of comovement. Our findings suggest that, while the average output correlation in the globalization period is substantially higher than that in the BW period for the United States, it is relatively stable for Japan over these two periods. The correlations between the growth rate of U.S. output and that of other G-7 countries are typically higher in the globalization period than they are in the BW period. The correlations of the U.S. output growth with those of Canada, France, and the United Kingdom also increase over these two periods.

These observations are generally valid for consumption and investment correlations as well (Tables $6 \mathrm{~b}$ and $6 \mathrm{c}$ ). The growth rates of consumption and investment between the United States and most other G-7 countries become more synchronized during the period of globalization relative to the $\mathrm{BW}$ period. Overall, our findings suggest that business cycles in the United States become more correlated with most other G-7 countries' cycles during the globalization period.

Business cycles in Germany and Japan followed a different path, as the degree of comovement between the cycles in the major macroeconomic aggregates of these countries and those of several other G-7 countries decrease during the globalization period relative to the common shock period. Correlations of output, consumption, and investment growth fluctuations in Germany with the majority of G-7 countries are lower in the globalization period. In the case of Japan, correlations of investment with most other G-7 countries increase in the globalization period relative to the common shock period, but correlations of output and consumption growth with other G-7 countries go down during the same time interval.

\section{Explaining the Evolution and Sources of Comovement in the G-7 Countries}

In this sub-section, we analyze the sources of the comovement patterns documented above.

Several recent studies have examined the evolution of cyclical comovements in industrialized countries. Unlike the studies on the dynamics of volatility, the studies focusing on the time profile of cross-country business cycle correlations have been unable to provide a clear description of the evolution of business cycle comovement. ${ }^{18}$ For example, some of these studies document that there has been a decrease in the degree of comovement (see Heathcote and Perri (2002), Olivei (2000), and Otto, Voss, and Willard (2001)). Other studies find that there has been no discernible change in the degree of business cycle comovement (see Doyle

\footnotetext{
${ }^{18}$ There are a variety of reasons why various studies reach widely different results about the evolution of business cycle comovement. See Hideaki, Kose, and Prasad (2003) for a discussion of this issue and a detailed review of recent studies.
} 
and Faust (2002), Helbling and Bayoumi (2002), and Stock and Watson (2003)). And some studies document that business cycle linkages have become stronger over time (e.g., Kose, Prasad, and Terrones (2003b)).

It is hard to make a conclusive statement about the changes in the synchronization of business cycles in the G-7 countries over time. A possible reason is that cross-country correlations are able to capture only the contemporaneous comovement in macroeconomic variables. To overcome this problem, Kose, Otrok, and Whiteman (2003b) estimate a dynamic latent factor model for the three subperiods used in this paper. Their model accounts for the dynamic comovement in output, consumption, and investment series of the G-7 economies. In particular, they decompose the macroeconomic fluctuations in these variables into the following: (i) the world factor (common across all variables/countries); (ii) country factors (common across aggregates in a country); and (iii) factors specific to each variable. They utilize variance decompositions to determine the fraction of variance of each macroeconomic aggregate that is attributable to the world factor, the country factor or the idiosyncratic component. ${ }^{19}$

Kose, Otrok, and Whiteman (2003b) find that the degree of comovement of business cycles of major macroeconomic aggregates across the G-7 countries has increased during the globalization period. To evaluate the role of globalization in driving the degree of comovement, they compare the period of globalization with the BW period (Table 7a). The average output variance explained by the world factor has increased from roughly 6 percent in the first period to 19 percent in the globalization period. There has been a marginal increase in the average variance of consumption explained by the world factor in the globalization period relative to the first period. The average share of investment variance due to the world factor has tripled during the globalization period relative to the $\mathrm{BW}$ period.

The world factor is more important in explaining business cycles in the globalization period than in the first period in all countries except Germany and Japan (Table 7b). The Japanese economy suffered a prolonged recession that was aggravated by a sharp fall in asset prices and a severe banking crisis. The unification process and the Maastricht criteria forced Germany to implement a set of tight fiscal and monetary policies that resulted in a relatively long period of low growth during the 1990s. In other words, Germany and Japan are outliers because business cycles in these countries have been mostly driven by domestic forces during the period of globalization.

\section{Conchusions}

In this paper, we first provided some basic facts about the substantial increase in the volume of trade and financial flows during the past four decades. We studied how different types of developing countries have experienced the increase in global linkages by dividing developing

${ }^{19}$ Lumsdaine and Prasad (2002); Nadal-De Simone (2003); Bordo and Helbling (2003); and Kose, Otrok, and Whiteman (2003a) document that there is a significant common component in explaining business cycles in industrialized countries. 
countries into two coarse groups - more financially integrated (MFI) economies and less financially integrated (LFI) economies. In order to isolate the impact of common shocks from that of globalization during the past four decades, we considered the period from 1960 to 2002 as being composed of three distinct subperiods. We documented that there has been a dramatic expansion of cross-border asset trade since 1986, which marks the beginning of the third subperiod the period of globalization.

Next, we provided a descriptive empirical characterization of business-cycle dynamics for a large sample of developing and industrial economies. We found that the volatility of output and investment growth appears to have declined, on average, for all groups of countries in the globalization period. Although the volatility of consumption growth also declined for many countries over this period, it appears to have increased for those developing economies that participated most actively in the process of financial globalization. Stronger trade and financial linkages seemed to have strengthened the comovement of major macroeconomic aggregates across industrial countries. By contrast, correlations of developing country macroeconomic aggregates with corresponding "world" aggregates appear to have weakened slightly in the 1990 s.

Some of these empirical findings are not consistent with theoretical predictions. For example, it is hard to reconcile the observed increase in investment correlations and the decline in the volatility of investment over time with the predictions of theory, which suggest the opposite in response to stronger economic linkages between countries. Moreover, the evolution of volatility and comovement properties of business cycles in MFI economies has been quite contrary to the implications of economic theory.

Our regression results suggest that stronger global linkages led to higher output and consumption correlations across countries. However, an increase in the volatility of the terms of trade led to a decrease in the extent of business-cycle comovement. Neither the similarity of fiscal policy nor that of monetary policy appears to have a statistically significant impact on the degree of output comovement. We also studied the changes in the nature of G-7 business cycles over time using quarterly data. We documented that although the volatility of business cycles has been decreasing over time in the G-7 countries except Japan, most of the cross-country correlations have increased. We then provided a brief review of the literature focusing on the sources of dynamic comovement using factor models.

The results of this paper suggest several interesting future research topics. One of these topics is understanding how the design of fiscal and monetary policies is affected by the changes in characteristics of business cycles. Our next step in this research program is to examine the role played by economic policy in explaining cross-country business-cycle correlations and how this role has changed over time in response to developments in global financial and trade linkages. 
Table 1. Volatility of Annual Growth Rates of Selected Variables (Percentage standard deviations, medians for each group of countries)

\begin{tabular}{|c|c|c|c|c|}
\hline & \multirow{3}{*}{$\begin{array}{c}\text { Full Sample } \\
1960-99\end{array}$} & \multicolumn{3}{|c|}{ Period } \\
\hline & & \multicolumn{3}{|c|}{ Common } \\
\hline & & BW & Shocks & Globalization \\
\hline \multicolumn{5}{|l|}{ Output } \\
\hline \multirow[t]{2}{*}{ Full Sample } & 3.75 & 2.93 & 3.62 & 2.56 \\
\hline & {$[0.20]$} & {$[0.28]$} & {$[0.25]$} & {$[0.26]$} \\
\hline \multirow[t]{2}{*}{ Industrial Countries } & 2.18 & 2.06 & 2.24 & 1.75 \\
\hline & {$[0.23]$} & {$[0.27]$} & {$[0.17]$} & {$[0.20]$} \\
\hline \multirow[t]{2}{*}{ Developing Countries } & 4.28 & 3.61 & 4.14 & 3.22 \\
\hline & {$[0.24]$} & {$[0.37]$} & {$[0.33]$} & {$[0.37]$} \\
\hline \multirow[t]{2}{*}{ MFIs } & 3.84 & 3.25 & 3.83 & 3.33 \\
\hline & {$[0.20]$} & {$[0.41]$} & {$[0.43]$} & {$[0.67]$} \\
\hline \multirow[t]{2}{*}{ LFIs } & 4.67 & 4.27 & 4.38 & 3.08 \\
\hline & {$[0.35]$} & {$[0.67]$} & {$[0.62]$} & {$[0.41]$} \\
\hline \multicolumn{5}{|l|}{ Consumption } \\
\hline \multirow[t]{2}{*}{ Full sample } & 5.12 & 3.95 & 5.12 & 4.05 \\
\hline & {$[0.51]$} & {$[0.47]$} & {$[0.51]$} & {$[0.59]$} \\
\hline \multirow[t]{2}{*}{ Industrial countries } & 2.37 & 1.72 & 2.38 & 1.78 \\
\hline & {$[0.31]$} & {$[0.30]$} & {$[0.24]$} & {$[0.21]$} \\
\hline \multirow[t]{2}{*}{ Developing countries } & 6.09 & 5.09 & 6.19 & 5.23 \\
\hline & {$[0.36]$} & {$[0.30]$} & {$[0.49]$} & {$[0.43]$} \\
\hline \multirow[t]{2}{*}{ MFIs } & 5.19 & 4.39 & 5.19 & 4.68 \\
\hline & {$[0.51]$} & {$[0.43]$} & {$[0.59]$} & {$[0.54]$} \\
\hline \multirow[t]{2}{*}{ LFIs } & 6.61 & 5.53 & 7.30 & 5.80 \\
\hline & {$[0.78]$} & {$[0.64]$} & {$[0.81]$} & {$[0.79]$} \\
\hline \multicolumn{5}{|l|}{ Investment } \\
\hline \multirow[t]{2}{*}{ Full sample } & 15.39 & 14.10 & 15.18 & 12.67 \\
\hline & {$[0.97]$} & {$[1.65]$} & {$[1.28]$} & {$[0.71]$} \\
\hline \multirow[t]{2}{*}{ Industrial countries } & 8.16 & 7.99 & 9.72 & 7.49 \\
\hline & {$[0.83]$} & {$[0.74]$} & {$[0.84]$} & {$[0.74]$} \\
\hline \multirow[t]{2}{*}{ Developing countries } & 18.01 & 17.37 & 18.32 & 14.91 \\
\hline & {$[1.34]$} & {$[1.52]$} & {$[1.01]$} & {$[0.96]$} \\
\hline \multirow{2}{*}{ MFIs } & 15.39 & 15.38 & 14.05 & 12.93 \\
\hline & {$[1.70]$} & {$[1.84]$} & {$[1.95]$} & {$[1.30]$} \\
\hline \multirow[t]{2}{*}{ LFIs } & 20.39 & 19.01 & 19.87 & 15.93 \\
\hline & {$[1.77]$} & [1.91] & {$[1.75]$} & {$[1.80]$} \\
\hline
\end{tabular}

Notes: Standard errors are reported in brackets. All of the statistics are significant at the 1 percent level. 
Table 2. Correlations with "World" Macroeconomic Aggregates

(Medians for each group)

\begin{tabular}{|c|c|c|c|c|}
\hline & \multirow{2}{*}{$\begin{array}{c}\text { Full Sample } \\
1960-99\end{array}$} & \multicolumn{3}{|c|}{ Period } \\
\hline & & BW & $\begin{array}{l}\text { Common } \\
\text { Shocks }\end{array}$ & Globalization \\
\hline \multicolumn{5}{|l|}{ Output } \\
\hline Full sample & $\begin{array}{c}0.18 \\
{[0.04]^{* * *}}\end{array}$ & $\begin{array}{c}0.11 \\
{[0.04]^{* *}}\end{array}$ & $\begin{array}{c}0.20 \\
{[0.06]^{* * *}}\end{array}$ & $\begin{array}{r}0.03 \\
{[0.06]}\end{array}$ \\
\hline Industrial countries & $\begin{array}{c}0.52 \\
{[0.05]^{* * *}}\end{array}$ & $\begin{array}{r}0.19 \\
{[0.13]}\end{array}$ & $\begin{array}{c}0.39 \\
{[0.12]^{* * *}}\end{array}$ & $\begin{array}{c}0.46 \\
{[0.11]^{* * *}}\end{array}$ \\
\hline Developing countries & $\begin{array}{c}0.10 \\
{[0.03]^{* * *}}\end{array}$ & $\begin{array}{c}0.09 \\
{[0.04]^{* *}}\end{array}$ & $\begin{array}{c}0.18 \\
{[0.07] * *}\end{array}$ & $\begin{array}{r}-0.01 \\
{[0.05]}\end{array}$ \\
\hline MFIs & $\begin{array}{c}0.12 \\
{[0.05]^{* *}}\end{array}$ & $\begin{array}{r}0.02 \\
{[0.06]}\end{array}$ & $\begin{array}{r}0.18 \\
{[0.12]}\end{array}$ & $\begin{array}{r}0.02 \\
{[0.09]}\end{array}$ \\
\hline LFIs & $\begin{array}{c}0.09 \\
{[0.04]^{* *}}\end{array}$ & $\begin{array}{r}0.09 \\
{[0.07]}\end{array}$ & $\begin{array}{c}0.18 \\
{[0.10] *}\end{array}$ & $\begin{array}{r}-0.03 \\
{[0.10]}\end{array}$ \\
\hline \multicolumn{5}{|l|}{ Consumption } \\
\hline Full sample & $\begin{array}{c}0.12 \\
{[0.04]^{* * *}}\end{array}$ & $\begin{array}{r}0.02 \\
{[0.05]}\end{array}$ & $\begin{array}{c}0.14 \\
{[0.06]^{* *}}\end{array}$ & $\begin{array}{r}-0.03 \\
{[0.06]}\end{array}$ \\
\hline Industrial countries & $\begin{array}{c}0.45 \\
{[0.06]^{* * *}}\end{array}$ & $\begin{array}{r}0.06 \\
{[0.08]}\end{array}$ & $\begin{array}{c}0.33 \\
{[0.08]^{* * *}}\end{array}$ & $\begin{array}{c}0.57 \\
{[0.12]}\end{array}$ *** \\
\hline Developing countries & $\begin{array}{r}0.02 \\
{[0.03]}\end{array}$ & $\begin{array}{r}-0.03 \\
{[0.06]}\end{array}$ & $\begin{array}{r}-0.02 \\
{[0.06]}\end{array}$ & $\begin{array}{c}-0.08 \\
{[0.04] *}\end{array}$ \\
\hline MFIs & $\begin{array}{r}0.04 \\
{[0.06]}\end{array}$ & $\begin{array}{r}0.06 \\
{[0.09]}\end{array}$ & $\begin{array}{r}-0.03 \\
{[0.08]}\end{array}$ & $\begin{array}{r}-0.03 \\
{[0.14]}\end{array}$ \\
\hline LFIs & $\begin{array}{r}0.01 \\
{[0.05]}\end{array}$ & $\begin{array}{r}-0.03 \\
{[0.10]}\end{array}$ & $\begin{array}{r}0.04 \\
{[0.09]}\end{array}$ & $\begin{array}{r}-0.08 \\
{[0.07]}\end{array}$ \\
\hline \multicolumn{5}{|l|}{ Investment } \\
\hline Full sample & $\begin{array}{c}0.10 \\
{[0.03]^{* * *}}\end{array}$ & $\begin{array}{r}0.06 \\
{[0.06]}\end{array}$ & $\begin{array}{r}0.06 \\
{[0.05]}\end{array}$ & $\begin{array}{r}0.03 \\
{[0.06]}\end{array}$ \\
\hline Industrial countries & $\begin{array}{c}0.40 \\
{[0.09]^{* * *}}\end{array}$ & $\begin{array}{r}0.25 \\
{[0.17]}\end{array}$ & $\begin{array}{c}0.40 \\
{[0.17]^{* *}}\end{array}$ & $\begin{array}{c}0.51 \\
{[0.11]}\end{array} * * *$ \\
\hline Developing countries & $\begin{array}{r}0.01 \\
{[0.03]}\end{array}$ & $\begin{array}{r}0.01 \\
{[0.05]}\end{array}$ & $\begin{array}{r}0.01 \\
{[0.05]}\end{array}$ & $\begin{array}{r}-0.03 \\
{[0.04]}\end{array}$ \\
\hline MFIs & $\begin{array}{l}-0.01 \\
{[0.05]}\end{array}$ & $\begin{array}{r}0.09 \\
{[0.06]}\end{array}$ & $\begin{array}{r}-0.03 \\
{[0.07]}\end{array}$ & $\begin{array}{r}-0.03 \\
{[0.11]}\end{array}$ \\
\hline LFIs & $\begin{array}{r}0.01 \\
{[0.05]}\end{array}$ & $\begin{array}{r}-0.10 \\
{[0.09]}\end{array}$ & $\begin{array}{r}0.01 \\
{[0.07]}\end{array}$ & $\begin{array}{r}-0.03 \\
{[0.08]}\end{array}$ \\
\hline
\end{tabular}

Notes: World aggregates are represented by the G-7 aggregates. The group of industrial countries in this table excludes the G-7. Standard errors are reported in brackets. The symbols ${ }^{*},{ }^{* *}$, and ${ }^{* * *}$, indicate statistical significance at the 10 percent, 5 percent, and 1 percent levels, respectively. 
Table 3. Determinants of Correlations

\begin{tabular}{|c|c|c|c|c|}
\hline & \multicolumn{2}{|c|}{ Output } & \multicolumn{2}{|c|}{ Consumption } \\
\hline & OLS & $\Gamma \mathrm{IV}$ & OLS & IV \\
\hline \multirow[t]{2}{*}{ Current account restrictions } & 0.044 & 0.068 & -0.016 & -0.016 \\
\hline & {$[0.072]$} & {$[0.078]$} & {$[0.075]$} & {$[0.083]^{*}$} \\
\hline \multirow[t]{2}{*}{ Trade openness } & -0.001 & -0.001 & 0.001 & 0.001 \\
\hline & {$[0.001]$} & {$[0.002]$} & {$[0.001]$} & {$[0.003]$} \\
\hline \multirow{2}{*}{ Trade linkages with G-7 } & 0.005 & 0.011 & 0.004 & 0.001 \\
\hline & {$[0.002] * *$} & {$[0.005]^{* *}$} & {$[0.002]^{*}$} & {$[0.005]$} \\
\hline \multirow[t]{2}{*}{ Capital account restrictions } & -0.144 & -0.152 & 0.044 & -0.003 \\
\hline & {$[0.084]^{*}$} & {$[0.114]$} & {$[0.089]$} & {$[0.096]$} \\
\hline \multirow[t]{2}{*}{ Financial openness } & 0.002 & -0.001 & 0.002 & -0.003 \\
\hline & {$[0.002]$} & {$[0.009]$} & {$[0.002]$} & {$[0.007]$} \\
\hline \multirow[t]{2}{*}{ Relative income } & 0.021 & 0.074 & -0.019 & -0.038 \\
\hline & {$[0.201]$} & {$[0.247]$} & {$[0.195]$} & {$[0.237]$} \\
\hline \multirow[t]{2}{*}{ Terms of trade volatility } & -0.672 & -0.765 & -0.808 & -0.874 \\
\hline & {$[0,257] * * *$} & {$[0.286]^{* * *}$} & {$[0.316]^{* *}$} & {$[0.352]^{* * *}$} \\
\hline \multirow[t]{2}{*}{ Monetary policy } & 0.000 & 0.003 & -0.004 & -0.006 \\
\hline & {$[0.011]$} & {$[0.011]$} & {$[0.006]$} & {$[0.006]$} \\
\hline \multirow[t]{2}{*}{ Fiscal policy } & 0.076 & 0.076 & 0.174 & 0.176 \\
\hline & {$[0.103]$} & {$[0.096]$} & {$[0.055]^{* * *}$} & {$[0.058] * * *$} \\
\hline R-squared & 0.16 & 0.12 & 0.17 & 0.15 \\
\hline Observations & 250 & 243 & 250 & 243 \\
\hline Sargan & & 10.238 & & 9.402 \\
\hline p-value & & $\{0.176\}$ & & $\{0.225\}$ \\
\hline
\end{tabular}

Notes: The dependent variable is the correlation of each country's output or consumption growth with the corresponding world aggregate over each ten-year period. Regional and time (decade) dummies are included in all regressions. For the IV regressions, the instruments include relative income (versus U.S.) as of 1960, shares of agriculturc and manufacturing in total output in 1960, and dummies for oil-exporting countries, landlocked countries, countries in tropical climates, existence of multiple exchange rates and existence of export surrender requirements. Robust standard errors are reported in parenthesis. The symbols *, ${ }^{* *}$, and $* * *$ indicate statistical significance at the 10 percent, 5 percent, and 1 percent levels, respectively.

The Sargan test is for the validity of the instruments used in each regression. $p$-values are reported in brackets. 
Table 4. Determinants of Correlations

\begin{tabular}{|c|c|c|c|c|}
\hline & \multicolumn{2}{|c|}{ Output } & \multicolumn{2}{|c|}{ Consumption } \\
\hline & OLS & IV & OLS & IV \\
\hline \multirow[t]{2}{*}{ Current account restrictions } & 0.003 & -0.011 & -0.121 & -0.144 \\
\hline & {$[0.084]$} & {$[0.093]$} & {$[0.074]$} & {$[0.083]^{*}$} \\
\hline \multirow[t]{2}{*}{ Trade openness } & -0.002 & -0.002 & 0.002 & 0.003 \\
\hline & {$[0.001]$} & {$[0.002]$} & {$[0.001]$} & {$[0.003]$} \\
\hline \multirow[t]{2}{*}{ Trade linkages with G-7 } & 0.005 & 0.011 & 0.004 & 0,001 \\
\hline & {$[0.002]^{* *}$} & {$[0.005]^{* *}$} & {$[0.002] * *$} & {$[0.005]$} \\
\hline \multirow[t]{2}{*}{ Capital account restrictions } & -0.114 & -0.108 & 0.019 & -0.020 \\
\hline & {$[0.078]$} & {$[0.104]$} & {$[0.080]$} & {$[0.096]$} \\
\hline \multirow[t]{2}{*}{ Financial openness } & 0.002 & 0.000 & 0.001 & -0.003 \\
\hline & {$[0.002]$} & {$[0.008]$} & {$[0,002]$} & {$[0,007]$} \\
\hline \multirow{2}{*}{ Relative income } & -0.017 & 0.044 & -0.012 & -0.081 \\
\hline & {$[0.193]$} & {$[0.240]$} & {$[0.190]$} & {$[0.237]$} \\
\hline \multirow[t]{2}{*}{ Terms of trade volatility } & -0.659 & -0.765 & -0.940 & -0.992 \\
\hline & {$[0.284] * *$} & {$[0.313]^{* *}$} & {$[0.331]^{* * *}$} & {$[0.352] * * *$} \\
\hline \multirow[t]{2}{*}{ Monetary policy } & 0.000 & 0.003 & -0.004 & -0.007 \\
\hline & {$[0.011]$} & {$[0.011]$} & {$[0.006]$} & {$[0.006]$} \\
\hline \multirow[t]{2}{*}{ Fiscal Policy } & 0.077 & 0.074 & 0.176 & 0.177 \\
\hline & {$[0.102]$} & {$[0.097]$} & {$[0.055] * * *$} & {$[0.058]^{* * *}$} \\
\hline R-squared & 0.16 & 0.12 & 0.18 & 0.16 \\
\hline Observations & 252 & 243 & 252 & 243 \\
\hline Sargan & & 9.257 & & 9.491 \\
\hline p-value & & $\{0.235\}$ & & $\{0.219\}$ \\
\hline
\end{tabular}

Notes: This table is the same as Table 3 except that the first regressor is now the Sachs-Warner (1995) openness variable, updated by Easterly, Levine and Rodman (2003). As before, the dependent variable is the correlation of cach country's output or consumption growth with the corresponding world aggregate over each ten-year period. Regional and time (decade) dummies are included in all regressions. For the IV regressions, the instruments include relative income (versus U.S.) as of 1960, shares of agriculture and manufacturing in total output in 1960, and dummies for oil-exporting countries, landlocked countries, countries in tropical climates, existence of multiple exchange rate and existence of export surrender requirements. Robust standard errors are reported in parentheses. The symbols ${ }^{*},{ }^{* *}$, and *** indicate statistical significance at the 10 percent, 5 percent, and 1 percent levels, respectively. The Sargan test is for the validity of the instruments used in each regression. p-values are reported in brackets. 
Table 5. Volatility

\begin{tabular}{|c|c|c|c|c|c|c|c|}
\hline & Full & BW & Common Shocks & Globalization & $F 12$ & $F 13$ & $F 23$ \\
\hline \multicolumn{8}{|l|}{ Output } \\
\hline Canada & 0.90 & 0.98 & 0.98 & 0.68 & & $* *$ & $* *$ \\
\hline France & 0.75 & 0.87 & 0.60 & 0.49 & ** & $* *$ & \\
\hline Germany & 1.02 & 1.08 & 1.08 & 0.86 & & * & * \\
\hline Italy & 0.97 & 1.17 & 1.03 & 0.56 & & $* *$ & $* *$ \\
\hline Japan & 1.25 & 1.16 & 0.92 & 1.07 & & & \\
\hline United Kingdom & 1.00 & 1.06 & 1.33 & 0.54 & & ** & $* *$ \\
\hline United States & 0.88 & 0.93 & 1.12 & 0.54 & & $* *$ & $* *$ \\
\hline Mean & 0.97 & 1.04 & 1.01 & 0.68 & & & \\
\hline \multicolumn{8}{|l|}{ Consumption } \\
\hline Canada & 0.94 & 1.12 & 1.00 & 0.69 & & ** & $* *$ \\
\hline France & 0.86 & 0.92 & 0.90 & 0.58 & & $* *$ & $* *$ \\
\hline Germany & 1.03 & 0.79 & 1.07 & 1.05 & $*$ & & \\
\hline Italy & 0.78 & 0.79 & 0.68 & 0.62 & & $*$ & \\
\hline Japan & 1.40 & 1.00 & 1.30 & 1.42 & & & \\
\hline United Kingdom & 1.15 & 1.17 & 1.52 & 0.67 & $*$ & $* *$ & ** \\
\hline United States & 0.71 & 0.70 & 0.88 & 0.49 & & $* *$ & $* *$ \\
\hline Mean & 0.98 & 0.93 & 1.05 & 0.79 & & & \\
\hline \multicolumn{8}{|l|}{ Investment } \\
\hline Canada & 2.32 & 2.11 & 2.60 & 2.26 & & & \\
\hline France & 4.75 & 8.50 & 1.58 & 1.34 & $* *$ & $* *$ & \\
\hline Germany & 2.75 & 2.72 & 2.84 & 2.65 & & & \\
\hline Italy & 2.00 & 2.63 & 1.72 & 1.58 & $* *$ & $* *$ & \\
\hline Japan & 2.53 & 2.61 & 2.17 & 1.90 & & $* *$ & \\
\hline United Kingdom & 2.93 & 3.32 & 3.00 & 2.53 & & $* *$ & \\
\hline United States & 2.04 & 1.68 & 2.77 & 1.51 & $* *$ & & ** \\
\hline Mean & 2.76 & 3.37 & 2.38 & 1.97 & & & \\
\hline
\end{tabular}

Notes: To test the stability of volatility, the $F$-test is employed. The symbols $\left({ }^{* *}\right)$ and $\left({ }^{*}\right)$ indicate statistically significant differences at the 5 percent point and 10 percent point levels, respectively. 
Table 6a. Comovement--Output

\begin{tabular}{|c|c|c|c|c|c|c|c|}
\hline & Full & $\mathrm{BW}$ & Common Shocks & Globalization & $Z 12$ & $Z 13$ & $Z 23$ \\
\hline \multicolumn{8}{|c|}{ United States } \\
\hline Canada & 0.51 & 0.36 & 0.56 & 0.61 & & $*$ & \\
\hline France & 0.16 & -0.13 & 0.31 & 0.31 & $* *$ & & \\
\hline Germany & 0.24 & 0.03 & 0.40 & 0.15 & $* *$ & & \\
\hline Italy & 0.14 & 0.01 & 0.17 & 0.15 & & & \\
\hline Japan & 0.14 & -0.01 & 0.34 & -0.12 & * & & $* *$ \\
\hline United Kingdom & 0.23 & 0.01 & 0.30 & 0.43 & & $* *$ & \\
\hline Mean & 0.24 & 0.05 & 0.35 & 0.26 & & & \\
\hline \multicolumn{8}{|c|}{ Germany } \\
\hline Canada & 0.24 & 0.15 & 0.40 & -0.07 & & & $* *$ \\
\hline France & 0.38 & 0.01 & 0.64 & 0.42 & $* *$ & $* *$ & $*$ \\
\hline Italy & 0.15 & -0.22 & 0.35 & 0.21 & $* *$ & $* *$ & $* *$ \\
\hline Japan & 0.20 & -0.02 & 0.26 & 0.06 & & & \\
\hline United Kingdom & 0.36 & 0.42 & 0.45 & 0.04 & & $* *$ & $* *$ \\
\hline United States & 0.24 & 0.03 & 0.40 & 0.15 & $* *$ & & \\
\hline Mean & 0.26 & 0.06 & 0.42 & 0.13 & & & \\
\hline \multicolumn{8}{|c|}{ Japan } \\
\hline Canada & 0.24 & 0.11 & 0.29 & -0.06 & & & \\
\hline France & 0.48 & 0.38 & 0.36 & 0.13 & & & \\
\hline Germany & 0.20 & -0.02 & 0.26 & 0.06 & & & \\
\hline Italy & 0.30 & 0.30 & 0.13 & -0.01 & & & \\
\hline United Kingdom & 0.20 & 0.08 & 0.45 & 0.07 & $* *$ & & $* *$ \\
\hline United States & 0.14 & -0.01 & 0.34 & -0.12 & $*$ & & $* *$ \\
\hline Mean & 0.26 & 0.14 & 0.30 & 0.01 & & & \\
\hline
\end{tabular}

Notes: To test the stability of comovement, the Z-test is employed. The symbols $\left({ }^{* *}\right)$ and $\left({ }^{*}\right)$ indicate statistically significant differences at 5 percent and 10 percent levels, respectively. 
Table 6b. Comovement-Consumption

\begin{tabular}{|c|c|c|c|c|c|c|c|}
\hline & Full & $\mathrm{BW}$ & Common Shocks & Globalization & $Z 12$ & 213 & $Z 23$ \\
\hline \multicolumn{8}{|c|}{ United States } \\
\hline Canada & 0.38 & 0.33 & 0.36 & 0.43 & & & \\
\hline France & 0.16 & -0.27 & 0.38 & 0.12 & $* *$ & $* *$ & \\
\hline Germany & 0.17 & -0.10 & 0.34 & -0.01 & $* *$ & & $* *$ \\
\hline Italy & 0.00 & -0.25 & -0.01 & 0.01 & & & \\
\hline Japan & 0.21 & 0.19 & 0.24 & 0.03 & & & \\
\hline United Kingdom & 0.17 & 0.02 & 0.23 & 0.31 & & & \\
\hline Mean & 0.18 & -0.01 & 0.26 & 0.15 & & & \\
\hline \multicolumn{8}{|c|}{ Germany } \\
\hline Canada & 0.19 & 0.15 & 0.25 & 0.05 & & & \\
\hline France & 0.39 & 0.03 & 0.50 & 0.36 & $* *$ & $*$ & \\
\hline Italy & 0.18 & -0.19 & 0.13 & 0.16 & & & \\
\hline Japan & 0.23 & -0.11 & 0.26 & 0.11 & $*$ & $*$ & \\
\hline United Kingdom & 0.20 & -0.06 & 0.54 & -0.10 & $* *$ & & \\
\hline United States & 0.17 & -0.10 & 0.34 & -0.01 & $* *$ & & \\
\hline Mean & 0.23 & -0.04 & 0.34 & 0.09 & & & \\
\hline \multicolumn{8}{|c|}{ Japan } \\
\hline Canada & 0.06 & -0.03 & -0.03 & -0.01 & & & \\
\hline France & 0.30 & 0.02 & 0.35 & 0.06 & $*$ & & \\
\hline Germany & 0.23 & -0.11 & 0.26 & 0.11 & $*$ & & \\
\hline Italy & 0.32 & 0.20 & 0.19 & 0.09 & & & \\
\hline United Kingdom & 0.08 & 0.08 & 0.28 & -0.15 & & & $* *$ \\
\hline United States & 0.21 & 0.19 & 0.24 & 0.03 & & & \\
\hline Mean & 0.20 & 0.06 & 0.21 & 0.02 & & & \\
\hline
\end{tabular}

Notes: To test the stability of comovement, the Z-test is employed. The symbols $\left({ }^{* *}\right)$ and $\left({ }^{*}\right)$ indicate statistically significant differences at the 5 percent and 10 percent levels, respectively. 
Table $6 \mathrm{c}$. Comovement-Investment

\begin{tabular}{|c|c|c|c|c|c|c|c|}
\hline & Full & BW & Common Shocks & Globalization & 212 & 213 & $Z 23$ \\
\hline & & & United States & & & & \\
\hline Canada & 0.25 & 0.29 & 0.29 & 0.18 & & & \\
\hline France & 0.01 & -0.07 & 0.17 & 0.18 & & & \\
\hline Germany & 0.21 & 0.09 & 0.30 & 0.17 & & & \\
\hline Italy & 0.15 & 0.01 & 0.33 & 0.09 & & & \\
\hline Japan & 0.11 & -0.05 & 0.34 & -0.10 & $* *$ & & $* *$ \\
\hline United Kingdom & 0.15 & 0.03 & 0.11 & 0.35 & & $*$ & \\
\hline \multirow[t]{2}{*}{ Mean } & 0.15 & 0.05 & 0.26 & 0.15 & & & \\
\hline & & & Germany & & & & \\
\hline Canada & 0.11 & 0.04 & 0.19 & 0.08 & & & \\
\hline France & 0.13 & 0.06 & 0.37 & 0.34 & & & \\
\hline Italy & 0.06 & -0.28 & 0.19 & 0.29 & $* *$ & $* *$ & \\
\hline Japan & 0.21 & 0.07 & 0.19 & 0.26 & & & \\
\hline United Kingdom & 0.14 & 0.32 & -0.14 & 0.23 & $* *$ & & $* *$ \\
\hline United States & 0.21 & 0.08 & 0.31 & 0.19 & & & \\
\hline \multirow[t]{2}{*}{ Mean } & 0.14 & 0.05 & 0.19 & 0.23 & & & \\
\hline & & & Japan & & & & \\
\hline Canada & 0.10 & 0.02 & 0.08 & 0.18 & & & \\
\hline France & 0.01 & -0.19 & 0.32 & 0.28 & $* *$ & & $* *$ \\
\hline Germany & 0.21 & 0.07 & 0.19 & 0.26 & & & \\
\hline Italy & 0.25 & 0.22 & 0.16 & 0.26 & & & \\
\hline United Kingdom & 0.24 & 0.27 & 0.16 & 0.26 & & & \\
\hline United States & 0.12 & -0.03 & 0.35 & -0.10 & $* *$ & $* *$ & \\
\hline Mean & 0.16 & 0.06 & 0.21 & 0.19 & & & \\
\hline
\end{tabular}

Notes: To test the stability of comovement, the Z-test is employed. The symbols $\left({ }^{* *}\right)$ and $\left({ }^{*}\right)$ indicate statistically significant differences at the 5 percent and 10 percent levels, respectively. 
Table 7a. Average Variance Explained by the World Factor (in percent)

\begin{tabular}{lcccc}
\hline & Full Sample & Bretton Woods & Common Shocks & Globalization \\
\cline { 2 - 5 } & 26.46 & 6.38 & 36.86 & 18.71 \\
Output & 15.38 & 9.25 & 19.76 & 10.77 \\
Consumption & 16.26 & 8.39 & 19.35 & 23.06 \\
Investment & & & & \\
\hline
\end{tabular}

Notes: In each cell, the average fraction of variance attributable to the world factor is reported. See Kose, Otrok, and Whiteman (2003b) for details.

Table 7b. Output Variance Explained by the World Factor (in percent)

\begin{tabular}{lccc}
\hline & BW & Common Shocks & Globalization \\
\hline Germany & 20.55 & 79.89 & 4.72 \\
Japan & 1.86 & 20.09 & 0.78 \\
United States & 4.63 & 32.76 & 16.55 \\
G-7 Average & 6.38 & 36.86 & 18.71 \\
& & & \\
\hline
\end{tabular}

Notes: In each cell, the fraction of variance attributable to the world factor is reported. Sec Kose, Otrok, and Whiteman (2003b) for details. 
Figure 1. Rising Global Linkages

a. Gross Financial Flows: MFIs

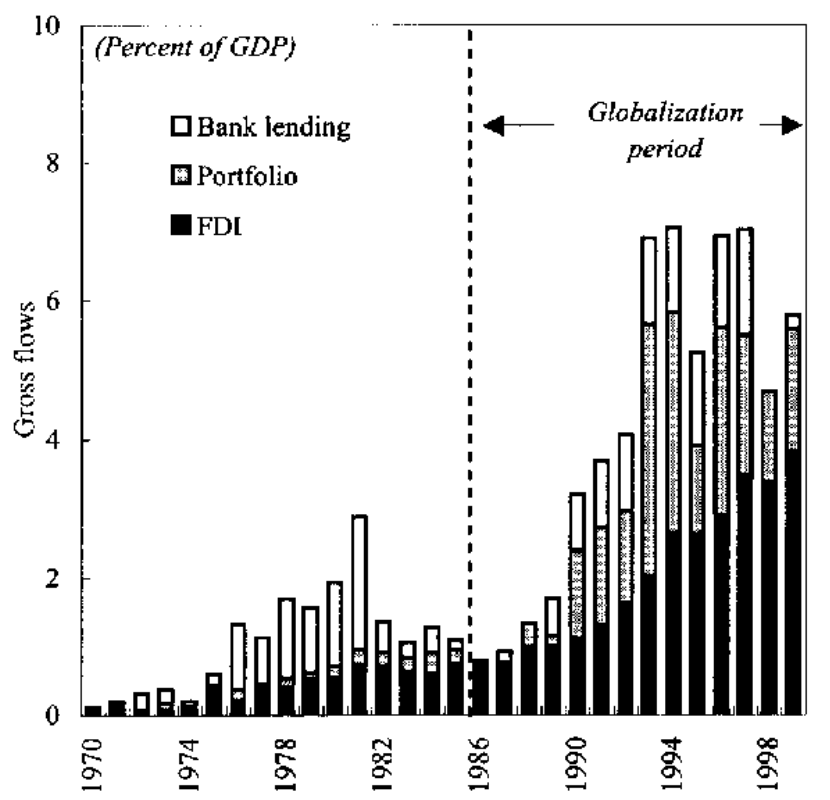

c. US Stock of Foreign Asset Holdings as Fraction of Total Capital

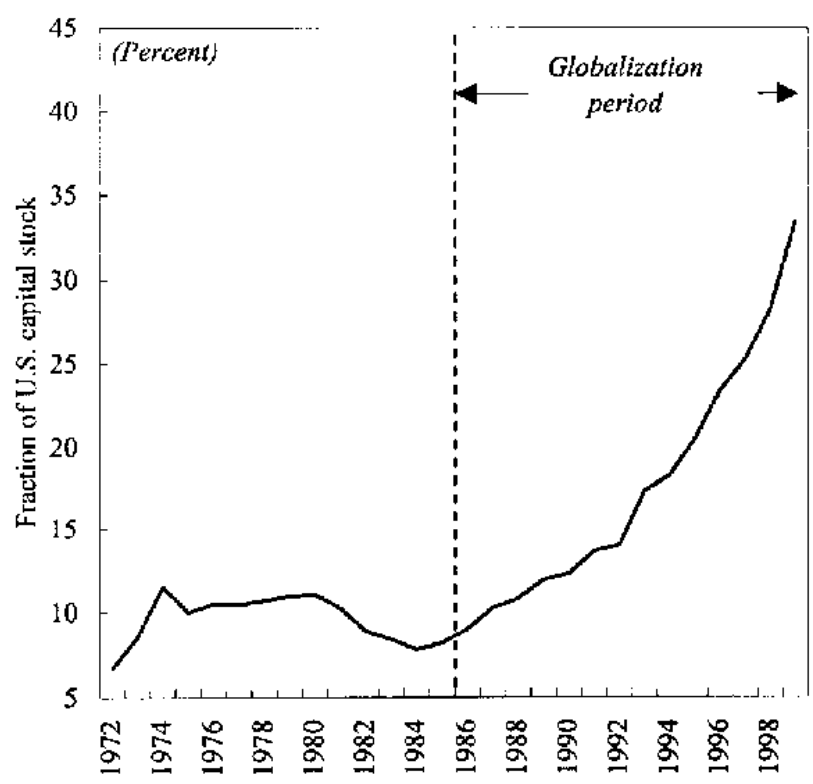

b. Gross Financial Flows: LFIs

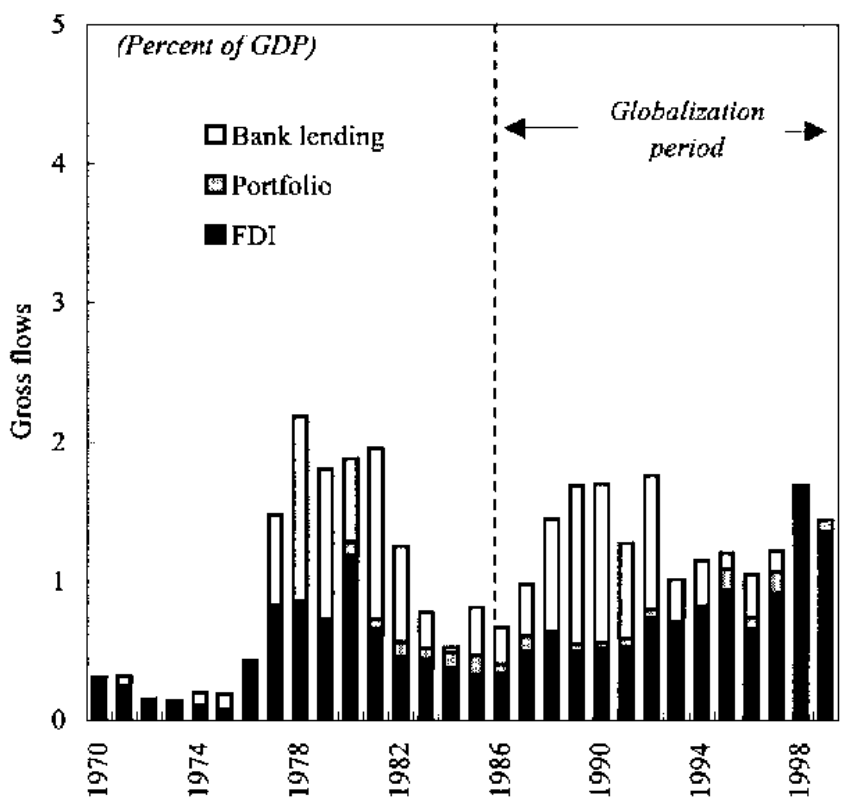

d. World Merchandise Exports

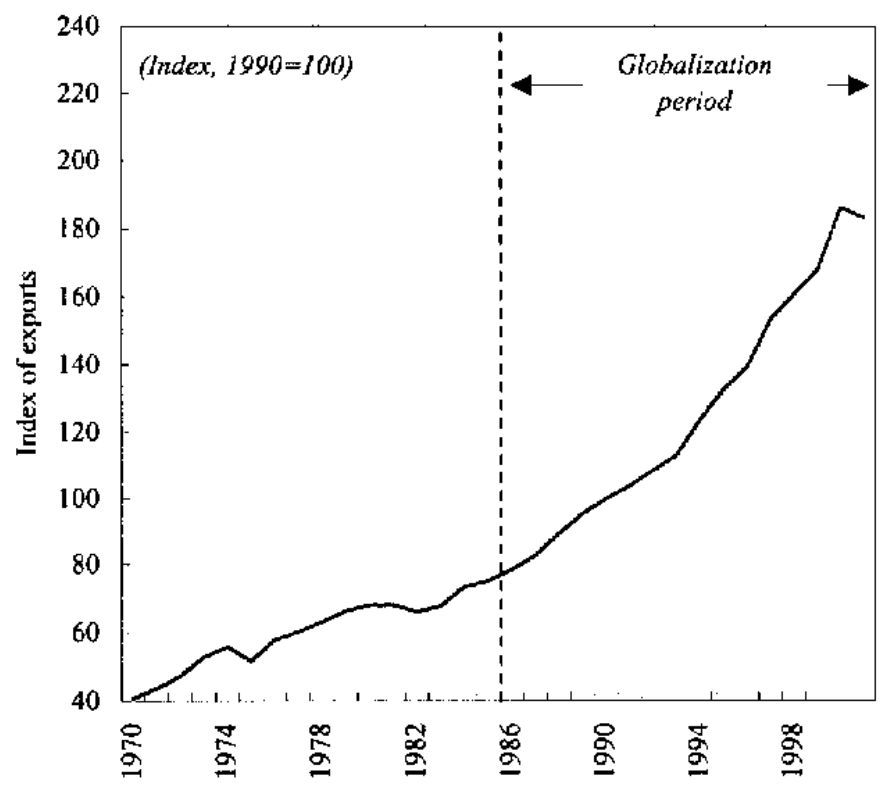

Notes: The top two panels do not have the same scale. 
Figure 2. Growing Linkages Around the World

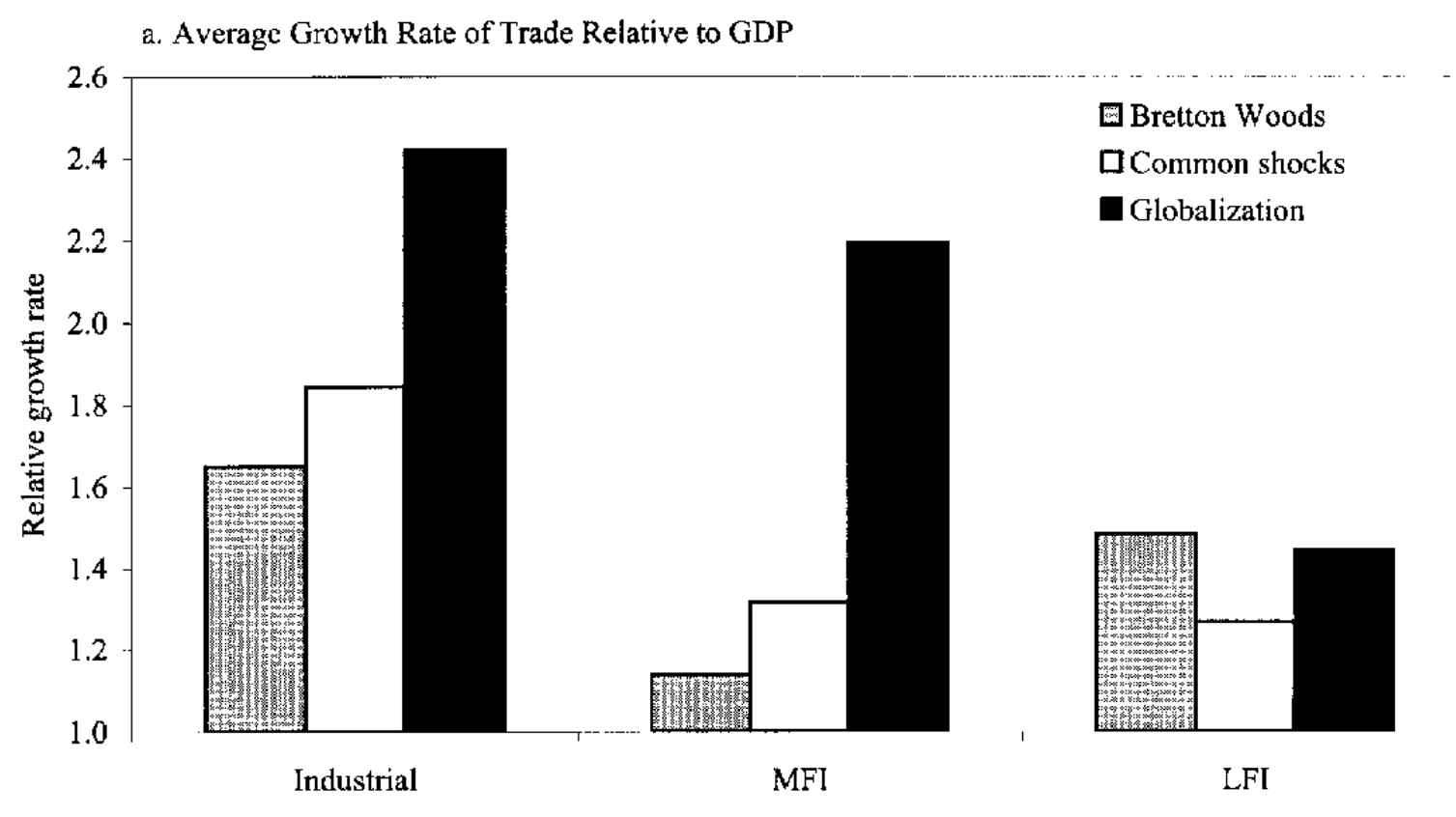

b. Gross Private Capital Flows to GDP

25 (Percent of GDP)

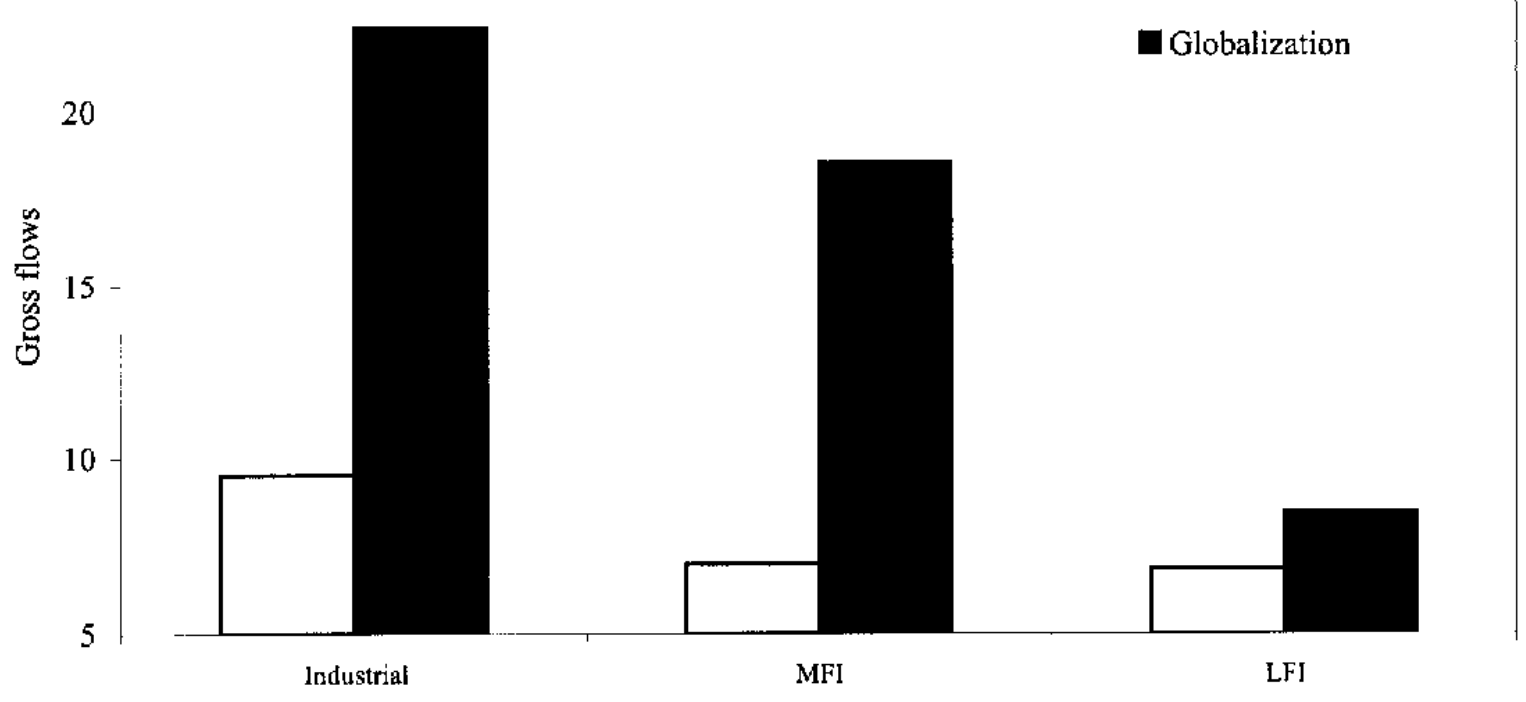


Figure 3. Growing Linkages Among the G-7
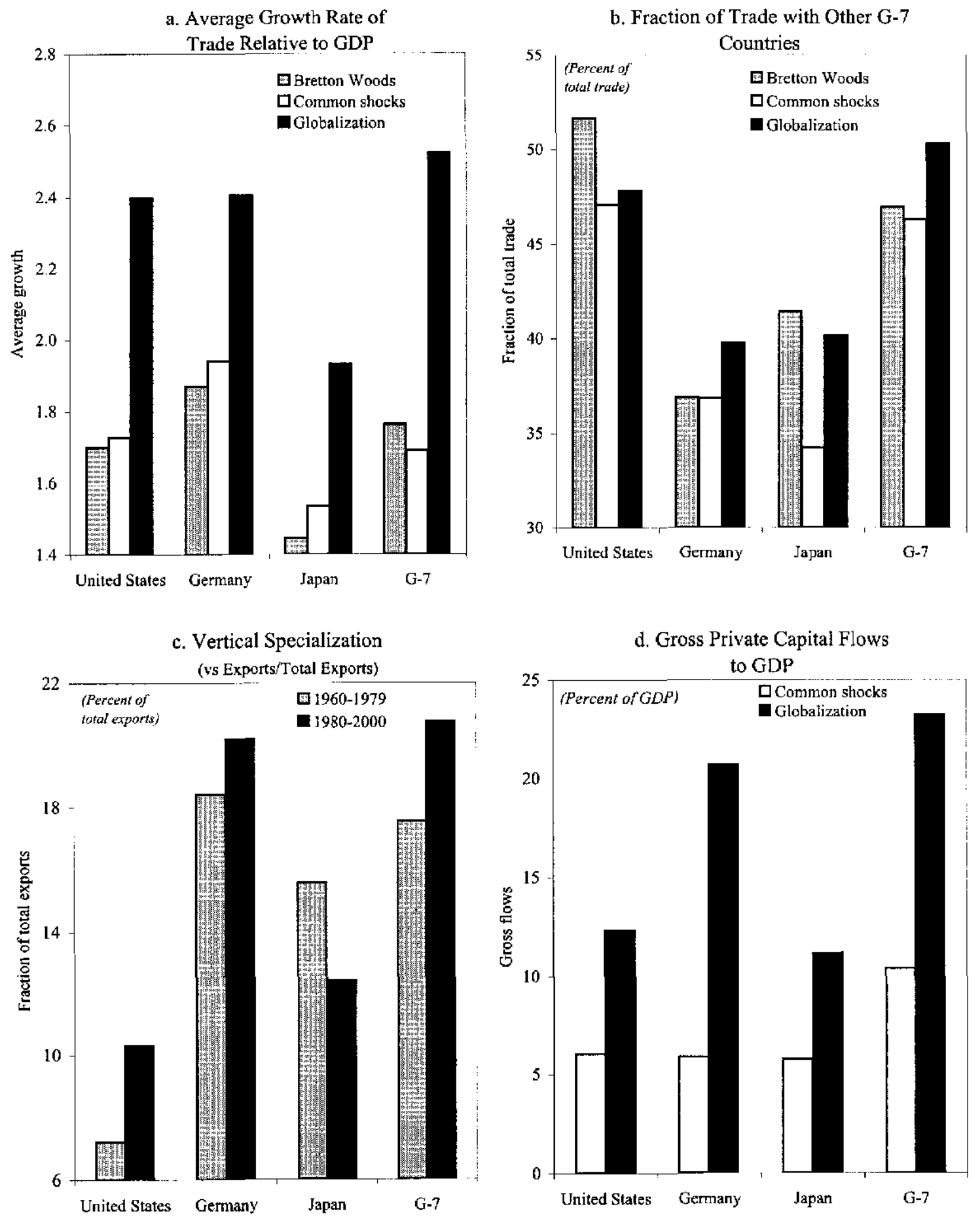
Figure 4. Output, Consumption, and Investment Volatility

Industrial Countries
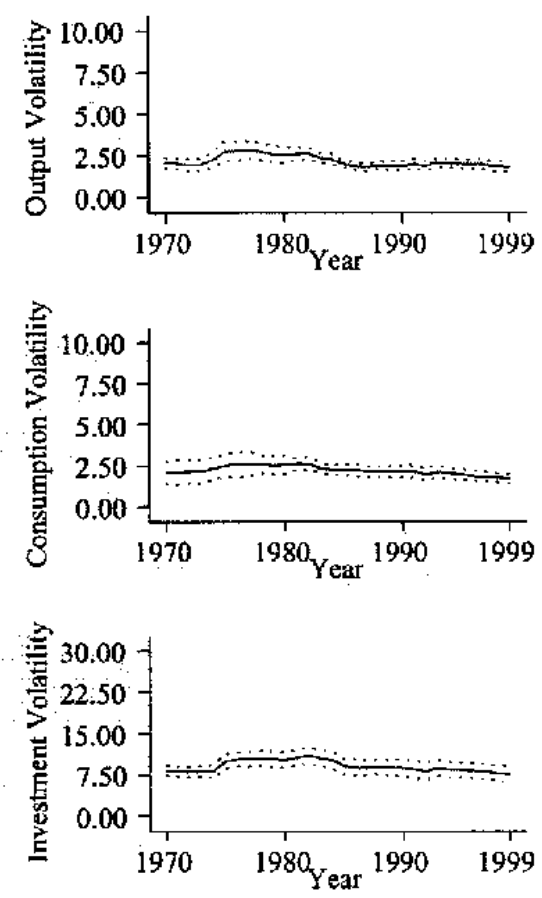

MFIs
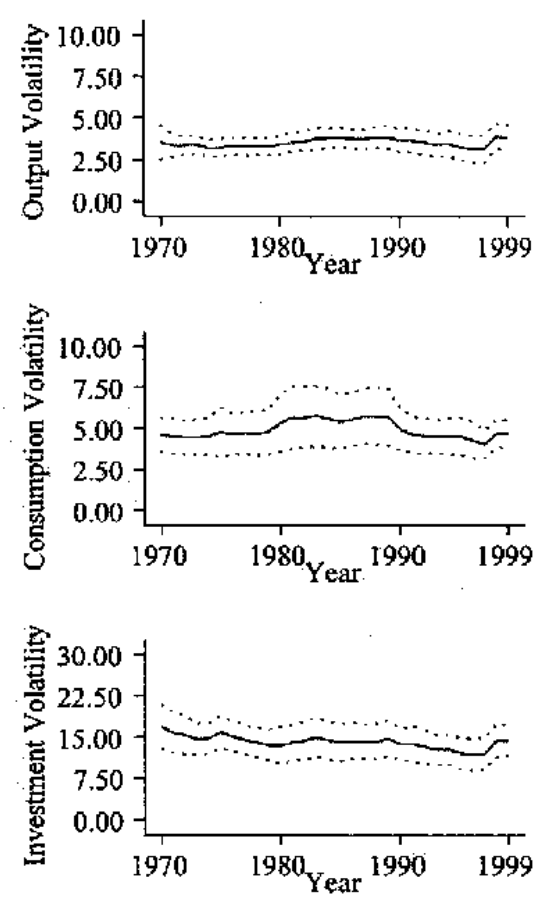

LFIs
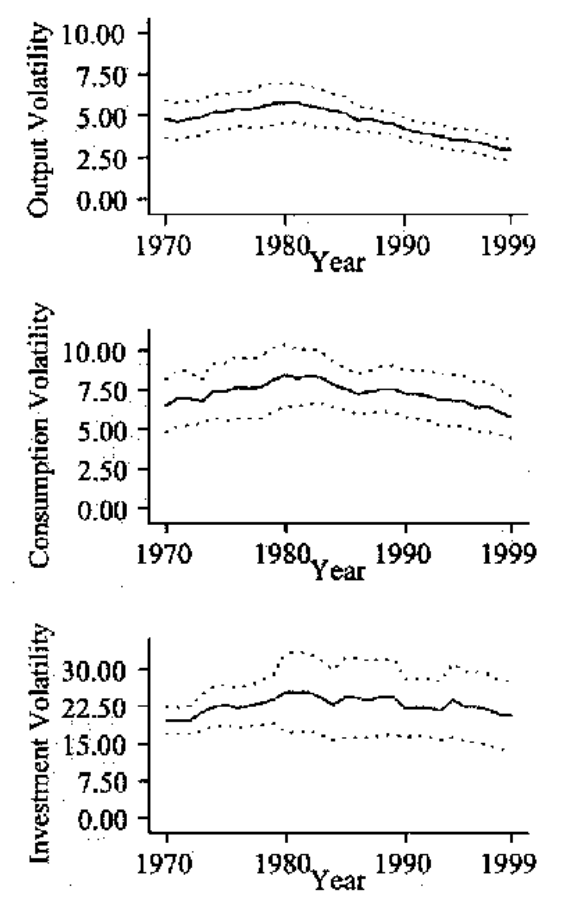

Note: Dotted lines are two standard error bands 
Figure 5. Output, Consumption, and Investment Correlation

Industrial Countries
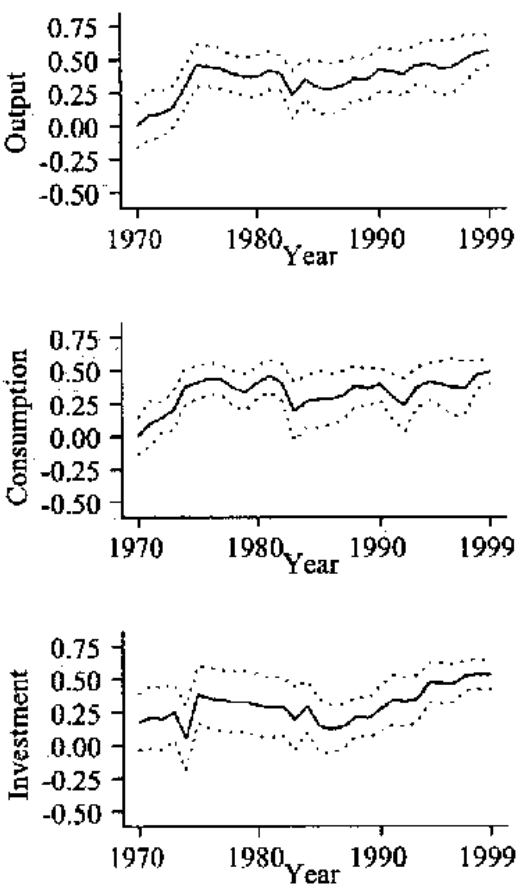

MFIs
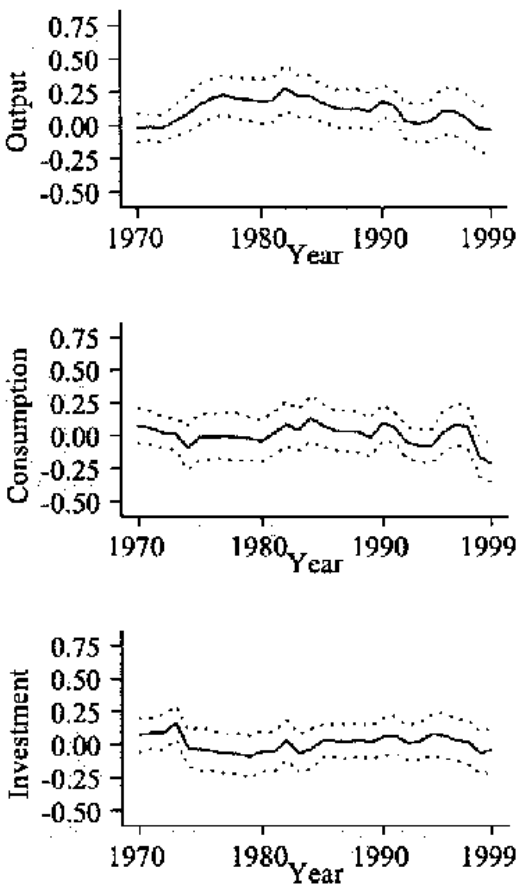

LFIs
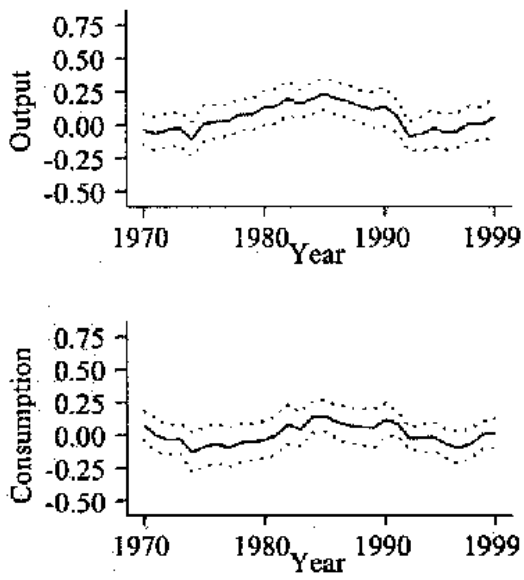

Note: Dotted lines are two standard cror bands

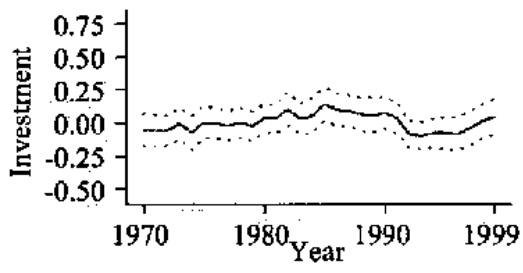




\section{References}

Agénor, P. R., C.J. McDermott, and E.S. Prasad, 2000, "Macroeconomic Fluctuations in Developing Countries: Some Stylized Facts," World Bank Economic Review, Vol. 14, pp. 251-85.

Ahmed, S., B.W. Ickes, P. Wang, and B.S. Yoo, 1993, "International Business Cycles," American Economic Review, Vol. 83, pp. 335-59.

Baxter, M., 1991, "Business Cycles, Stylized Facts, and the Exchange Rate Regime: Evidence from the United States," Journal of International Money and Finance, Vol. 10, pp. 71-88.

—, and A.C. Stockman, 1989, "Business Cycles and the Exchange Rate Regime: Some International Evidence," Journal of Monetary Economics, Vol. 23, pp. 377-400.

Blanchard, O., and J. Simon, 2001, "The Long and Large Decline in U.S. Output Volatility," Brookings Papers in Economic Activity, Vol. 1, pp. 135-74.

Bordo, M. D., and T. Helbling, 2003, "Have National Business Cycles Become More Synchronized?", IMF Working Paper (Washington: International Monetary Fund).

Buch, C.M., J. Dopke, and C. Picrdzioch, 2002, "Business Cycle Volatility in Germany," Working Paper, Kiel Institute for World Economics.

Calderon, C. A., A. E. Chong, and E. H. Stcin, 2002, "Trade Intensity and Business Cycle Synchronization: Are Developing Countries any Different?", Manuscript, InterAmcrican Development Bank.

Chen, H., and K. Yi, 2002, "Myth and Reality on the Globalization of Production and International Trade", Working Paper, Federal Reserve Bank of New York.

Clark, T. E., and E. van Wincoop, 2001, "Borders and Business Cycles," Journal of International Economics, Vol. 55, pp. 59-85.

Cole, H., 1993, "lhe Macroeconomic Effects of World Trade in Financial Assets," Federal Reserve Bank of Minneapolis Quarterly Review, Vol. 17, pp. 12-21.

Dijk, D., D.R. Osborn, and M. Sensier, 2002, "Changes in the Variability of the Business Cycle in the G7 Countries," Working Paper, University of Manchester.

Doyle, B., and J. Faust, 2002, "Breaks in the Variability and Comovement of G-7 Economic Growth," Working Paper, Federal Reserve Board of Governors.

Easterly, W., R. Levine, and D. Roodman, 2003, "New Data, New Doubts: A Comment on Burnside and Dollar's "Aid, Policies, and Growth," National Bureau of Economic Research (Cambridge, MA), Working Paper No. 9846. 
Frankel, J. A., and A. K. Rose, 1998, "The Endogeneity of the Optimum Currency Area Criteria," Economic Journal, Vol. 108, pp. 1009-25.

Gerlach, S., 1988, "World Business Cycles under Fixed and Flexible Exchange Rates," Journal of Money, Credit and Banking, Vol. 20, pp. 621-32.

Heathcote, J., and F. Perri, 2002a, "Financial Autarky and International Business Cycles," Journal of Monetary Economics, Vol. 49, pp. 601-28.

— 2002b, "Financial Globalization and Real Regionalization, National Bureau of Economic Research," (Cambridge, Massachusetts) Working Paper No. 9292.

IIelbling, T., and T. Bayoumi, 2002, "Are They $\Lambda 11$ in the Same Boat? The 2000-2001 Growth Slowdown and the G-7 Business Cycle Linkages," IMF Working Paper No. 03/46, (Washington: International Monetary Fund).

Hirata, H., 2003, "Business Cycle Facts of Japan," Working Paper, Brandeis University.

- M.A. Kose, and E.S. Prasad, 2003, "Changes in Volatility and Comovement in the OECD Countries," IMF Working Paper, forthcoming (Washington: International Monetary Fund).

Hummels, D., J. Ishii, and K.M. Yi, 2001, "The Nature and Growth of Vertical Specialization in World Trade," Journal of International Economics, Vol. 54, pp. 75-96.

Imbs, J., 2003, "Tradc, Finance, Spccialization and Synchronization," IMF Working Papcr No. 03/81, (Washington: International Monetary Fund).

International Monctary Fund, 2001, World Economic Oullook (Washington), October.

Kalemli-Ozcan, S., B. Sorensen, and O. Yosha, 2003, "Risk Sharing and Industrial Specialization: Regional and International Evidence," American Economic Review, forthcoming.

Kim, S. H., M.A. Kose, and M. Plummer, 2003, "Dynamics of Business Cycles in Asia," Review of Development Economics, Vol. 7, pp. 462-77.

Kose, M.A., 2002, "Explaining Business Cycles in Small Open Economies," Journal of International Economics, Vol. 56, pp. 299-327.

— 2003, "Globalization and Business Cycles in the United States," U.S. Selected Issues Papers, pp. 74-80.

- C. Otrok, and C. Whiteman, 2003a, "International Business Cycles: World, Region, and Country Specific Factors," American Economic Review, Vol. 93, pp. 1216-39. 
, 2003b, "Understanding the Evolution of World Business Cycles," IMF Working Paper, (Washington: International Monetary Fund).

Kose, M.A., E.S. Prasad, and M. Terrones, 2003a, "Financial Integration and Macroeconomic Volatility," IMF Staff Papers (Washington: International Monetary Fund), Vol. 50, pp. 119-42.

— 2003b, "How Does Globalization Affect the Synchronization of Business Cycles?", American Economic Review Papers and Proceedings, Vol. 93, pp. 57-62.

Kose, M.A., and K. Yi, 2001, "International Trade and Business Cycles: Is Vertical Specialization the Missing Link?", American Economic Review Papers and Proceedings, Vol. 91, pp. 371-75.

— , 2002, "The Trade Comovement Problem in International Macroeconomics," IMF Working Paper, forthcoming, (Washington: International Monetary Fund).

Lumsdaine, R. L., and E.S. Prasad, 2003, "Identifying the Common Component in International Economic Fluctuations," Economic Journal, Vol. 113, pp. 101-27.

McConnell, M., and G. P. Quiros, 2000, "Output Fluctuations in the United States: What IIas Changed Since the Early 1980s?" American Economic Review, Vol. 90, pp. 1464-76.

McConnell, M., P. C. Mosser, and G. P. Quiros, 1999, "A Decomposition of the Increased Stability of GDP Growth," FRB New York Current Issues in Economics and Finance, Vol. 5, pp. 1-5.

Mendoza, E.G., 1994, "The Robustness of Macrocconomic Indicators of Capital Mobility," in Leonardo Leiderman and Assaf Razin (eds.), "Capital Mobility: The Impact on Consumption, Investment, and Growth", Cambridge University Press, Cambridge, pp. 83-111.

- 1995, "The Terms of Trade, the Real Exchange Rate, and Economic Fluctuations," International Economic Review, Vol. 36, pp. 101-37.

Monfort, A., J. R. Renne, R. Rufle, and G. Vitale, 2002, "Is Economic Activity in the G-7 Synchronized? Common Shocks vs. Spillover Effects," Working Paper, European Central Bank.

Nadal-De Simone, Francisco, 2002, "Common and Idiosyncratic Components in Real Output: Further International Evidence," IMF Working Paper No. 02/229, (Washington: International Monetary Fund).

Obstfeld, M., and K. Rogoff, 1998, "Foundations of International Macroeconomics," The MIT Press. 
Olivei, G. P., 2000, "Consumption Risk-Sharing Across G-7 Countries," New England Economic Review of the Federal Reserve Bank of Boston, March/April, pp. 3-14.

Otto, G., G. Voss, and L. Willard, 2001, "Understanding OECD Output Correlations," Working Paper, University of New South Wales.

Prasad, E.S., K. Rogoff, S. Wei, and M.A. Kose, 2003, Effects of Financial Globalization on Developing Countries: Some Empirical Evidence, IMF Occasional Paper No. 220 (Washington: International Monetary Fund).

Razin, A., and A. K. Rose, 1994, "Business-cycle Volatility and Openness: An Exploratory Cross-sectional Analysis," in Leonardo Leiderman and $\Lambda$ ssaf Razin (eds.), "Capital Mobility: The Impact on Consumption, Investment, and Growth," Cambridge University Press. Cambridge, pp. 48-76.

Sachs, J., and A. Warner, 1995, "Economic Reform and the Process of Global Integration," Brookings Papers on Economic Activity, Vol. 2, pp. 523-64.

Smith, P. A., and P. M. Summers, 2002, "On the Interactions between Growth and Volatility in a Markov Switching Model of GDP," Working Paper, The University of Melbourne.

Stock, J. H., and M. W. Watson, 2003, "Understanding Changes in International Business Cycles," Working Paper, Harvard University.

Yi, K., 2003, "Can Vertical Specialization Explain the Growth of World Trade?" Journal of Political Economy, Vol. 11, pp. 52-102. 